\title{
IGNORANCE AND MISTAKE IN CRIMINAL LAW
}

\section{ROLLIN M. PERKINS $\dagger$}

Ignorance of law is no excuse, but mistake of fact is sufficient for exculpation if what was done would have been lawful had the facts been as they were reasonably supposed to be. This, like any other statement which seeks to compress a large field of law into the confines of a single sentence, is entirely too broad for certain specific situations. It indicates the result of the ordinary case, but its scope and limitations can be understood only in the light of important exceptions which have been recognized. A study of these problems may well be prefaced by brief reference to two words repeatedly encountered in this field.

It has been said that the words "ignorance" and "mistake" "do not import the same significance and should not be confounded. Ignorance implies a total want of knowledge in reference to the subject matter. Mistake admits a knowledge, but implies a wrong conclusion." 1 For the most part, however, this distinction has not been recognized." Some courts have brushed it aside as "a refinement too subtle to be applied to the every-day business of life", ${ }^{3}$ or one which "rests on no solid foundation".4 Most of them have merely ignored it.

Frequently these words have appeared in the phrases "ignorance of law" 5 and "mistake of fact". ${ }^{6}$ At times the word "ignorance" ?

† A. B., 19ro, University of Kansas; J.D., I912, Stanford University; S. J.D., I9I6, Harvard University; Professor of Law at University of Iowa; author of CASES on Criminal Procedure (3d ed. I929); Iowa Criminal Justice (i932); $A$ Rationale of Mens Rea, 52 HaRv. L. REv. 905 (I939); contributor to other legal periodicals.

I. Hulton v. Edgerton, 6 S. C. 485,489 (I875).

2. The most scholarly attempt to emphasize the distinction between the words "ignorance" and "mistake" is that by Professor Keedy in his article Ignorance and Mistake in the Criminal Law, 22 HARV. L. REv. 75 (1908). This distinction is not here insisted upon because the courts seem disinclined to recognize the approach from that angle. But the difference between certain types of misunderstanding, which Professor Keedy insisted upon, cannot be ignored.

3. Schlesinger v. United States, I Ct. Cl. I6, 25 (I863).

4. Champlin v. Laylin, 18 Wend. 407,416 (N. Y. 1837).

5. United States v. One Buick Coach Automobile, 34 F. (2d) 318, 320 (N. D. Ind 1929); Blumenthal v. United States, 88 F. (2d) 522, 530 (C. C. A. 8th, 1937); Weeks v. State, 24 Ala. App. 198, I99, 132 So. 870, 87 I (I93I) ; State v. Goodenow, $65 \mathrm{Me}$. 30,33 (1876); Commonwealth v. O'Conneli, 274 Mass. 3I5, 321, 174 N. E. 665, 667 (I93I) ; State v. Welch, 73 Mo. 284, 285 (I880); State v. Downs, II6 N. C. I064, 1066, 2I S. E. 689 (I895); Barronet's Case, I E. \& B. I, II8 Eng. Rep. R. 337 (I852); Holdies, The Common LaW (I88I) 47.

6. Stern v. State, 53 Ga. 229, 23I (1874); State v. O'Neil, I47 Iowa 513, 519, I26 N. W. 454, 456 (I9I0) ; Manning v. State, 43 Tex. Cr. R. 302, 303, 65 S. W. 920, 921 (Igor) ; Welch v. State, 46 Tex. Cr. R. 528, 530, 8r S. W. 50, $5 \mathrm{I}$ (I904); Chapman v. State, 77 Tex. Cr. R. 591, 595, I79 S. W. 570, 572 (I915); Regina v. Tolson, 23 Q. B. D. 168,190 (1889). Both frequently appear in the same sentence. See. People v. Cohn, 358 IIl. 326, 331, 193 N. E. I50, 153 (1934); Hunter v. State, I58 Tern. 63, 73, I2 S. W. (2d) 36r, 363 (I928).

7. Reynolds v. United States, 98 U. S. 145,167 (1878). 
or the word "mistake" 8 has been applied to both types of error, whereas elsewhere both words are coupled together in referring to each type. ${ }^{9}$ Whatever phraseology is employed it is necessary to explore to some depths the exact nature and effect of the misunderstanding in a particular case. The field of possible error is too great for any one simple solvent. It is important to inquire whether the ignorance or mistake was of law or of fact, but it is also necessary to carry the investigation far beyond this point.

IGNORANCE OR MISTAKe OF LAW

\section{The Maxim}

The maxim ${ }^{10}$ "ignorantia legis neminem excusat" ${ }^{11}$ ("ignorance of the law excuses no man") ${ }^{12}$ has appeared in many different forms. ${ }^{13}$ An occasional reference to it as a stern and inflexible rule of law without any exception ${ }^{14}$ is incorrect, ${ }^{15}$ but beyond any doubt it determines the result in all but very exceptional cases. Illustrative are the decisions holding ignorance of the violated law no defense to a prosecution for operating a gaming device, ${ }^{16}$ betting on a horse race, ${ }^{17}$ conducting a raffle, ${ }^{18}$ carrying concealed weapons, ${ }^{10}$ accepting unlawful rebates from carriers, ${ }^{20}$ altering public records, ${ }^{21}$ illegal sale of liquor, ${ }^{22}$ opening a saloon on election day (though after the close of the election itself), ${ }^{23}$ and obstructing a highway. ${ }^{24}$

8. Hamilton v. State, Ir5 Tex. Cr. R. 96, 97, 29 S. W. (2d) 777,778 (1930).

9. "His mistake or ignorance, if any, was one of law" and hence is no excuse. State v. Armington, 25 Minn. 29, 38 (I878).

". . . ignorance or mistake, as to these facts, honest and real . . . absolves from criminal responsibility." Dotson v. State, 62 Ala. I4I, I44 (1878).

I0. "A maxime is a proposition to be of all men confessed and granted without proofe, argument, or discourse." Co. LTTT. *67a. Needless to say there is no statement of law which is excluded from the field of discussion and argument at the present time.

II. State v. Boyett, 32 N. C. 336,343 (1849).

I2. Marmont v. State, 48 Ind. 2I, 31 (I874).

13. See Blumenthal v. United States, $88 \mathrm{~F}$. (2d) 522, 530 (C. C. A. 8th, I937); Weeks v. State, 24 Ala. App. 198, I99, 132 So. 870, 87I (I93I); People v. O’Brien, 96 Cal. 171, 176, x3 Pac. 45, 47 (1892); People v. Cohn, 358 I1l. 326, 331, I93 N. E. I50, I53 (I934); State v. O'Neil, I47 Iowa 5I3, 5I9, I26 N. W. 454, 456 (I9I0) ; State v. Goodenow, 65 Me. 30, 33 (I876) ; State v. Armington, 25 Minn. 29, 38 (I878); State v. Welch, 73 Mo. 284, 285 (I880) ; State v. Woods, ro7 Vt. 354, 356, x79 Atl. I, 2 (I935); Holames, The Common Law (I88I) 47.

I4. See Hoover v. State, 59 Ala. 57, 60 (1877).

I5. See State v. Goodenow, 65 Mie. 30,33 (I876); Cutler v. State, 36 N. J. I. 125, 127 (1873).

I6. Atkins v. State, 95 Tenn. 474,32 S. W. 391 (1895).

17. Debardelaben v. State, 99 Tenn. $649,42 \mathrm{~S}$. W. 684 (1897).

I8. Hickman v. State, 64 Tex. Cr. R. I6r, I4I S. W. 973 (I9ri).

19. Crain v. State, 69 Tex. Cr. R. 55 , I53 S. W. I55 (I9r3).

20. Armour Packing Co. v. United States, 200 U. S. 56 (I908).

2I. People v. O'Brien, 96 Cal. I7r, 3I Pac. 45 (I892).

22. State v. McBrayer, 98 N. C. 619, 2 S. E. 755 (I887).

23. Jones v. State, 32 Tex. Cr. R. 533, 25 S. W. I24 (I894).

24. State v. Mainey, 65 Ind. 404 (1879). 
It applies to the most serious offenses as well as to those of a less grievous nature. One, for example, who mistakenly believed he was privileged by law to use deadly force if necessary to protect his property was held guilty of criminal homicide for the fatal consequences of his defensive effort. ${ }^{25}$ It includes cases in which the misunderstanding of the law relates to a clause other than the penal provision violated. Thus mistake of law was no defense to a prosecution for practicing medicine without a license, where the defendant who was familiar with this law erroneously supposed his employment of a regularly licensed physician to work under his direction in his "cancer sanitarium" would satisfy the requirements of the license law. ${ }^{26}$ Furthermore, the mistaken notion that a "divorce" granted to one of the defendants was valid and permitted them to inter-marry did not save them from conviction under the "Blanket Act"; ${ }^{27}$ and an officer's erroneous belief that he was entitled to the fees of his office did not excuse him from the statutory crime of embezzlement by a public officer. ${ }^{28}$ The maxim applies although the mistaken belief is held by many other than the defendant; ${ }^{29}$ and even a foreigner who violates the law by a deed not recognized as a crime in his own country is not excused although he may never have heard of such a law. ${ }^{30}$

\section{Knowledge of Law Presumed}

"Every person is presumed to know the law",31 is one of the familiar phrases in this field. On rare occasions this presumption has beer challenged. "There is no presumption in this country that every person knows the law: it would be contrary to common sense and reason if it were so", said Mr. Justice Maule in an English case. ${ }^{32} \mathrm{He}$ did not recognize ignorance of law as an excuse but questioned the propriety of stating the rule in terms of a presumption. Such criticism, however, is based upon a misunderstanding of the word "presump-

25. Weston v. Commonwealth, III Pa. 25I, 2 Atl. IgI (I885). For a similar result under slightly different facts see People v. Cook, 39 Mich. 236 (I878).

26. Needham v. State, 55 Okla. Cr. R. 430,32 P. (2d) 92 (I934).

27. State v. Woods, I07 Vt. 354, I79 Atl. I (I935). The court emphasized that all the facts were known and the only misunderstanding was one of law. Cf. State v. Audette, 81 Vt. 400, 70 At1. 833 (I908).

28. Hunter v. State, 158 Tenn. 63, i2 S. W. (2d) 36r (I928). The specific intent required for ordinary embezzlement was not an element of this special statutory offense. Such a mistake would be an excuse if it negatived the existence of a required specific intent. See infra p. 45 .

29. State v. Southern Ry., I22 N. C. x052, 30 S. E. I33 (I898).

30. Rex v. Esop, 7 C. \& P. 456, 173 Eng. Rep. R. 203 (1836); Barronet's Case, I E. \& B. 5, II 8 Eng. Rep. R. 337 (IS52). This, however, may be considered on an application for executive clemency. Ibid.

3r. Weeks v. State, 24 Ala. App. I98, I99, I32 So. 870, 87I (I93r). See also Blumenthal v. United States, 88 F. (2d) 522, 530 (C. C. A. 8th, I937); People v. Cohn, 358 IIl. 326, 33I, I93 N. E. I50, I53 (I934); Marmont v. State, 48 Ind. 2I, 31 (1874); 4 BL. Coms. 27 ; I Hale, Pleas of the Crown 42.

32. Martindale v. Faulkner, 2 C. B. 706, 719, I35 Eng. Rep. R. II24, II29 (1846). 
tion". One of the three senses in which the term is used is to signify an inference of fact, but this "should be discarded as useless and confusing", 33 and is not at all the sense in which it is employed in the phrase under consideration. ${ }^{34}$ A true presumption is a rule of evidence which calls for a certain result in a particular case unless the party adversely affected comes forward with evidence to overcome it. ${ }^{35}$ This is sometimes referred to as a "prima facie presumption" to distinguish it from the so-called "conclusive presumption" which is a legal device in the form of a postulate used for the determination of a particular case whether it corresponds with the actual facts or not, as, for example, the conclusive presumption of delivery by all the prior parties to a megotiable instrument which has reached the hands of a holder in due course. $^{36}$

The latter use of the word "presumption", while not entirely free from objection, ${ }^{37}$ cannot be here ignored because this is the sense in which it has been commonly employed at this point in the criminal law. ${ }^{38}$ This meaning is emphasized by such familiar expressions as that every person "is bound to know the law" 39 or is "charged with knowledge of the law" 40 or "must know what the law is and act at his peril." "41 To say that everyone is conclusivly presumed to know the law is merely another form of saying that ignorance of the law is no excuse. There is also, however, a true presumption of knowledge of the law. Ordinarily this lies dormant because the case is not to be burdened with evidence which cannot affect the result. But in those exceptional situations in which ignorance of the law is an excuse, the case will still be decided as if the law had been known unless the defendant comes forward with evidence to show that he did not know. ${ }^{42}$ Stated differently, knowledge of the law is presumed; in most cases

33. 5 WIGMORE, EVIDENCE (2d ed. 1923) § $249 \mathrm{I}$.

34. "It is not so much a presumption of fact, as a fact, as it is a conclusion or presumption of the law. . . ". Commonwealth v. Jellico Coal Co., $96 \mathrm{Ky} .373,375,29$ S. W. 26 (I895).

35. 5 WiGMIORE, Evidence (2d ed. I923) § 2491 .

36. NEGOTIABLE INSTRUMENTS LAW, \$16.

37. 5 WIGMORE, EVIDENCE (2d ed. I923) \$ 2492.

38. ". . everyone is conclusively presumed to know the law. .. ." State v. Woods, I07 Vt. 354, 356, I79 Atl. I (I935). A study of other cases will show that this is ordinarily the intended meaning whether or not the word "conclusively" is added.

39. I Hale, Pleas of rHe Crown 42; State v. O'Neil, I47 Iowa 513, 519, I26 N.

W. 454, 456 (1910) ; State v. Goodenow, 65 Me. 30, 33 (1876).

40. Menefee v. State, I29 Tex. Cr. R. 375,87 S. W. (2d) 478 (1935).

4r. Needham v. State, 55 Okla. Cr. R. $430,434,32$ P. (2d) 92, 93 (1934).

42. "Assuming, without deciding, that the presumption was a rebuttable one it is to be observed that the defendants introduced no evidence in the attempt to rebut the presumption." Blumenthal v. United States, 88 F. (2d) 522, 539 (C. C. A. 8th, I937). Probably there are rare cases in which there is no presumption of knowledge of law either conclusive or disputable, as where the deed was prohibited by a law held unconstitutional by a prior decision which has been overruled after the deed was committed. See infra p. 44 . 
this presumption is conclusive but under exceptional circumstances it is disputable.

\section{The Intent to Commit Crime}

For reasons of policy, presently to be considered, a knowledge of the law is postulated; and except in unusual situations, also to be mentioned, this postulate may not be questioned. In this light it is possible to consider such cases in terms of mens rea. 'One who, knowing the law, by intention or criminal negligence brings about the result which the law was intended to prevent has unquestionably a socially blameworthy state of mind (in the absence of exculpating circumstances, such as compulsion).$^{43}$ If no additional mental element is required for conviction of the particular crime his state of mind meets the requirements of mens rea and he is guilty. Furthermore, this result is reached for the purposes of a particular case if this knowledge is established by a presumption as fully as if it had been proved by the introduction of evidence. ${ }^{44}$

The application of the mens rea concept may well be considered from another point of view. "In law, the commission of a crime consists in the joint operation of act and intent or criminal negligence." 45 Such a statement fails to give full scope to the psychical element of criminality which falls outside of the field of actual intent, ${ }^{46}$ but attention may be limited for the moment to intent alone. As a matter of law, an intent to do a certain deed, under circumstances which would amount to a crime if the intended result is achieved, is an intent to commit that very crime. If, for example, one person attacked another with intent to kill him, without justification or excuse, but in the sudden heat of passion engendered by such provocation that the crime would be manslaughter if death resulted, he has committed an assault with intent to commit manslaughter if the results were not fatal. ${ }^{47}$ It is not -

43. Compulsion might constitute an exculpating circumstance if the social harm was not too great. Rex v. Crutchley, 5 C. \& P. I33, I72 Eng. Rep. R. 909 (I83I). It is unnecessary to attempt here to consider in detail the various "excuses" such as insanity or even mistake of fact.

44. "He must be presumed to have known the provisions of s. 7 , whether he was actually acquainted with its terms or not. Then he knew that he had not the written consent of the mortgagee; and that knowledge was sufficient to make him aware that he was offending against the provisions of the Act, or, in other words, was sufficient to constitute what is known in law as mens rea." Bank of New South Wales v. Piper, [1897] A. C. 383, 390. See also Yoder v. State, 208 Ind. 50, 57, 194 N. E. 645 (1935); State v. Boyett, 32 N. C. 336,344 (1849).

45. Brown v. State, 28 Ark. I26, I28 (1873). See also Hoover v. State, 59 Ala. 57, 60 (1877); State v. Blue, 17 Utah 175, 180, 53 Pac. 978 (1898).

46. In malice aforethought, for example, the law takes notice of an attitude of mind in the nature of a wanton and reckless disregard of human life which falls between an intent to kill and criminal negligence.

47. Feagle v. State, 55 Fla. I3, 46 So. I82 (1908) ; Robinson v. State, I52 Ind. 304,53 N. E. 223 (1898); State v. McGuire, 87 Iowa I42, 54 N. W. 202 (I893) ; State v. Murray, 83 Kan. I48, Iro Pac. I03 (1910); State v. Calligan, I7 N. H. 253 (1845). These cases are based upon statute. There was no offense known as assault with intent to commit manslaughter at common law. 
an assault with intent to commit murder even if he supposed such a killing would be murder; nor would his notion that such a homicide is excusable change the result in the other direction. The law applies its own labels to intents as well as to results.

"It is very true", said the Alabama court, "that to constitute a crime there must be both an act and an intent. But, in such a case as this, it is enough if the act be knowingly and intentionally committed. The law makes the act an offence, and does not go farther and require proof that the offenders intended by the prohibited act, to violate the law." ${ }^{48}$ The same idea has been repeated in different forms. ${ }^{49}$ The intent to commit crime "is not the intent to violate the law but the-intentional doing the act which is a violation of law". ${ }^{50}$ It is an intent to do what the law calls a crime, whatever the actor himself may call it. A word of caution, however, may well be added at this point. If for guilt of a particular offense, some special mental element is required, such as that the prohibited deed be done "corruptly", the law itself does not apply the label "crime" to such a deed in the absence of the required mental element. Hence the innocent intent to perform such a deed in the bona fide belief of its propriety is not an intent to commit crime. ${ }^{51}$

\section{Reason for the Maxim}

While the "ignorance of law is no excuse" maxim may be rationalized with the mens rea concept, it should be frankly recognized that the former is in the nature of an exception to the basic principles upon which the latter is grounded. Mere logic would seem to indicate that the maxim should be abrogated entirely. But logic is the servant of the law, not its master; and iogical abstractions must give way in the presence of overbalancing considerations. This invites attention to the considerations upon which the maxim is supported.

These considerations are matters of "public policy" 52 or "public necessity". 33 "The welfare of society and the safety of the state" 54 have been felt to require this maxim "in order practically to administer

48. Hoover v. State, 59 Ala. 57, 60 (I877). See also People v. Dillon, I99 Cal. I, 248 Pac. 230 (I926) ; Kennedy v. State, 46 Ga. App. 42, I66 S. E 442 (I932).

49. See Weeks v. State, 24 Alla. App. 198, I99, I32 So. 870, 87 I (I93I); People v. Whitney, 57 Cal. App. 449, 452, 207 Pac. 698, 699 (I922).

50. State v. Downs, II6 N. C. 1064, 1066, 21 S. E. 689 (IS95). The same court said: "Knowledge that he was carrying the weapon concealed is equivalent, under the statute, to the criminal intent to conceal which is required by law to exist, there being no lawful excuse for carrying it." State v. Simmons, 143 N. C. 6I3, 6I7, 56 S. E. 7or, 703 (1907).

51. See infra p. 48.

52. State v. O'Neil, I47 Iowa 513,519, I26 N. W. 454,456 (Igro).

53. People v. O'Brien, 96 Cal. I7I, I76, 31 Pac. 45, 47 (1892).

54. Ibid. "Without it the court would be powerless to maintain any effective and valuable administration of the Criminal Code." Commonwealth v. Jellico Coal Co., 96 Ky. 373, 376, 29 S. W. 26 (I895). 
justice among men." "5s "If a person accused of crime", said the California court, "could shield himself behind the defense that he was ignorant of the law which he violated, immunity from punishment would in most cases result. . . . The plea would be universally made, and would lead to interminable questions incapable of solution." 56 If the social harm in a particular case is slight and the ignorance of the law on the part of the offender is fairly obvious, the state may wisely refrain from prosecution in his case. In certain other cases ignorance of law may be considered by the court in mitigation of punishment, ${ }^{57}$ or may be made the basis of an application for executive clemency. ${ }^{58}$ But if such ignorance were available as a defense in every criminal case, this would be a constant source of confusion to juries, and it would tend to encourage ignorance at a point where it is peculiarly important to the state that knowledge should be as widespread as is reasonably possible. ${ }^{59}$ In the language of one of the giants of the profession, this is a point at which "justice to the individual is rightly outweighed by the larger interests on the other side of the scales." 60

\section{Exceptions}

The possibility of exceptions must be studied in the light of the considerations underlying the maxim. As it is founded upon matters of policy deemed sufficient to require results other than would be reached by logic, the first search for limitations should be at points where the foundations of the maxim fail to give support while other considerations of policy point definitely in a different direction. Since this search will reveal certain important exceptions it is necessary to qualify the ordinary statement of mens rea in this field by recognizing ignorance of law in these unusual situations as a special circumstance of exculpation. ${ }^{61}$ At some points the policy which calls for exemption from guilt on this ground is so strong that ignorance of law may constitute a defense even in prosecutions for the so-called "public torts" 62 .

55. Marmont v. State, 48 Ind. 2r, 31 ( 1874$)$.

56. People v. O'Brien, g6 Cal. I7I, 176, 3 I Pac. 45, 47 (I892).

57. Re Russell, [Igor] A. C. 446; People v. O'Brien, 96 Cal. I7I, 3I Pac. 45 (1892) ; State v. Goodenow, 65 Me. 30 (1876).

58. Rex v. Bailey, Russ. \& Ry., I, I68 Eng. Rep. R. 65I (I800) ; Barronet's Case, I E. \& B. I, II 8 Eng. Rep. R. 337 (Q. B. 1852).

59. "One who is bound to obey the law ought not to be allowed to say that he was ignorant of it." State v. O'Neil, I47 Iowa 513, 519, 126 N. W. 454, 456 (1910).

60. Holmes, The Comaron LAw (r88r) 48.

6r. The statement may be in some such form as this: an intent to do a deed which is a crime is in juridical contemplation an intent to commit that crime even if the actor believes the law to be otherwise, unless the ignorance of law is in such an exceptional situation as to constitute a special circumstance of exculpation.

62. See Beale, Cases on Cruminal Law (4th ed. 1928) 129. Often they are called offenses malum prothibitum as distinguished from offenses malum in se. See People v. Ferguson, I34 Cal. App. 4I, 52, 24 P. (2d) 965, 970 (I933). 
or "civil offenses" ${ }^{63}$ for which the normal requirement of mens rea is wanting. ${ }^{64}$ And here will be found cases in which the result-diametrically opposed to the general statement-is that ignorance of the law will excuse while reasonable mistake of fact will not. ${ }^{65}$

\section{Reliance upon Legal Advice}

Ignorance of law will not excuse him who violates it even if he had been told in advance that such conduct would be lawful. ${ }^{66}$ This is held to be the result even if the erroneous legal advice was received from a reputable attorney, ${ }^{67}$ on the ground that a contrary result "would be placing the advice of counsel above the law itself." 68 To the extent, however, that some exception is recognized on other grounds, advice of counsel is admissible if it tends to establish ignorance of law on the part of the defendant. ${ }^{69}$

The arguments used to support the position taken with reference to advice of counsel seem peculiarly unconvincing. Ignorance of law based upon advice of a reputable attorney would not present to the jury "questions incapable of solution". Insistence, as in cases of recognized exceptions to the maxim, that the thing done must not be obviously anti-social in character and that the belief in the legality of the conduct must be in good faith, would seem to be adequate safeguards. It would not be surprising if some courageous court should lead the way for a new development along this line by including a proper case of this nature among the exceptions to the maxim.

At some extreme points exceptions have already been made to the rule that reliance upon legal advice is no excuse. If the offense charged is the violation of a law which forbids the doing of certain things without securing a permit from a specified commission or department, the bona fide reliance upon advice received from that very commission or department to the effect that contemplated action falls without the

63. This phrase is used for the same purpose by Professor Gausewitz. Legis., Criminal Laze-Reclassification of Certain Offenses as Civil Instead of Criminal (1937) I2 WIS. L. Rev. 365.

64. That mens rea is not required for convictions of such offenses unless added by the terms of a particular statute, see Sayre, Public Welfare Offenses (1933) 33 CoL. L. Rev. 55.

65. Compare McKnight v. State, I7I Tenn. 574, I06 S. W. (2d) 556 (I937), with People v. Ferguson, I34 Cal. App. 4I, 24 P. (2d) 965 (I933).

66. State v. Goodenow, 65 Mie. 30 (I876) (advice by magistrate) ; State v. Simmons, I43 N. C. 6I3, $56 \mathrm{~S}$. E. 70I (Ig07) (advice by court clerk).

67 . State v. Hughes, 58 Iowa 165 , in N. W. 706 (iS82); State v. Armington, 25 Minn. 29 (I878); Weston v. Commonwealth, III Pa. 25I, 2 Atl. I9I (I885); Hunter v. State, I 58 Tenn. 63 , I2 S. W. (2d) 36 r (r928).

68. Needham v. State, 55 Okla. Cr. R. 430, 434, 32 P. (2d) 92, 93 (1934). "If ignorance of counsel would excuse violations of the criminal law, the more ignorant counsel could manage to be the more valuable and sought after, in many cases, would be his advice." State v. Downs, II6 N. C. 1064, 1066, 2r S. E. 689 (I895).

69. State v. McKinney, 42 Iowa 205 ( 1875 ); Commonwealth v. Bradford, 9 Metc. 268 (Mass. I845); see Williamson v. United States, 207 U. S. 425,453 (I907). 
scope of the statute and hence requires no permit, has been held to bar a conviction. ${ }^{70}$ And one who made a full disclosure of the facts to the registration officers, or the judges of election, and was advised by them that he had a lawful right to vote, was held not guilty of unlawful registration as a voter, ${ }^{71}$ or illegal voting, ${ }^{72}$ although the advice he received was erroneous. Such decisions are unquestionably sound. Confidence in the government itself would be seriously undermined if citizens should be punished for apparently innocent deeds done in bona fide reliance upon the advice of officers who are authorized by the state to give such advice.

\section{Reliance upon Statute or Decision}

A statute which is unconstitutional is void; it is not a part of the law of the state. ${ }^{73}$ But it would be utterly unfair to the individual and very detrimental to the general social welfare to require each one to determine for himself, at his peril, to what extent if at all the legislature has overstepped its constitutional limitations. ${ }^{74}$ Hence the citizen is directed, in effect, to regulate his conduct according to the provisions of the statutory law, unless and until some part of it has been found to be invalid by judicial determination, ${ }^{75}$ or has been repealed by the legislative body. Prior to that time his mistaken belief in the unconstitutionality of the statute will give him no more protection than any other ignorance of law on his part; ${ }^{76}$ whereas his belief in the validity of the enactment will excuse him from criminal consequences of any conduct which would have been proper had his assumption been correct, even if the statute is subsequently held to be unconstitutional and void. ${ }^{77}$

For a similar reason the citizen is not permitted, except at his peril, to oppose his own belief to the judicial determination of the court

70. People v. Ferguson, 134 Cal. App. 4I, 24 P. (2d) 965 (I933). A third of a century earlier another court had reached a contrary result under very similar facts. State v. Foster, 22 R. I. I63, 40 Atl. 833 (I900). That decision however is an echo of the ancient notion that the ignorance of law maxim "has no exceptions". The later case is much more in line with the modern development.

7I. State v. White, 237 Mo. 208, 140 S. W. 896 (IgII).

72. State v. Pearson, 97 N. C. 434, I S. E. 9 I4 (1887).

73. "When a statute is adjudged to be unconstitutional, it is as if it had never been." I Cooley, Constitutional Limitations (8th ed. I927) 382.

74. "To require the citizen to determine for himself, at his peril, to what extent, if at all, the legislature has overstepped the boundaries defined by the constitution in passing this mass of statutes would be to place upon him an intolerable burden, one which it would be absolutely impossible for him to bear-a duty infinitely beyond his ability to perform." Lang v. Bayonne, 74 N. J. L. 455, 460, 68 Atl. 90, 92 (I906).

75. Claybrook v. State, 164 Tenn. $440,-51$ S. W. (2d) 499 (I932).

76. Hunter v. State, I 58 Tenn. 63 , I2 S. W. (2d) 36 I (I928); see State v. Sugarman, 126 Minn. 477,483, I48 N. W. 466,468 (1914). A religious belief that the bigamy law should not have been enacted is no excuse for a violation of the law. Reynolds v. United States, 98 U. S. I45, I67 (I878); Long v. State, I92 Ind. 524, I37 N. E. 49 (1922).

77. Claybrook v. State, I64 Tenn. 440, 5I S. W. (2d) 499 (I932). 
of last resort. His claim of a belief in the unconstitutionality of a statute which had previously been upheld by such a court would be even weaker than the ordinary plea of ignorance of law; ${ }^{78}$ whereas if the court of last resort has held the statute to be unconstitutional, no conduct (which would be socially acceptable in the absence of such legislation) in reliance upon such decision and before it is overruled, will merit punishment even if that court subsequently overrules the first decision and declares the statute to be constitutional and valid. ${ }^{79}$

It has also been held that a similar excuse will be recognized where a mistaken belief as to the law was based upon a decision of a lower court, prior to the contrary determination of a higher court. ${ }^{80}$ In spite of an indication to the contrary, ${ }^{81}$ this view is sound and it is to be expected that the development of the law will be definitely in that direction. The two pillars which support the maxim with its occasional harsh results are that recognition of ignorance of law as a defense would (I) present to the jury "questions incapable of solution" 82 and (2) encourage ignorance where knowledge is socially desirable. ${ }^{83}$ Both of these pillars are swept away where ignorance of law was due to reliance upon the decision of a court of record which was at the time of the reliance the last word in the jurisdiction upon that point. The evidence in such a case will be unusually clear cut ${ }^{84}$ and the average citizen should not be bound to know more law than a court of record.

Similar problems may arise in cases where there has been reliance upon judicial interpretation of statutes, which are subsequently given a different construction. These problems should be solved in the same general manner. Prior to judicial determination, however, where the question is not the validity of a statute but its proper interpretation, a problem of a very different nature may be presented. It is one thing to require the citizen to regulate his conduct according to the provi-

78. For example, ignorance of law may be an excuse if the prosecution is for an offense which requires a specific intent and such ignorance negatives this intent. See infra p. 45. But one who knew of a statute and the decision of the highest court upholding it would probably not be heard, even in such a case, to say that he was ignorant of the law because he believed the decision was erroneous.

A conviction of fraudulently appropriating money of a trust fund, in violation of a court order was affirmed although the defendant believed the court had made a mistake in the order. Commonwealth v. O'Connell, 274 Mass. 315,174 N. E. 665 (193I).

79. State v. O'Neil, r 47 lowa 5 1 3 , I26 N. W. 454 (19I0); sce Hunter v. State, I 58 Tenn. 63, 73, 12 S. W. (2d) 36I, 364 (1928); cf. Hoover v. State, 59 Ala. 57 (I877). The nature of the offense in the Alabama case, miscegenation, may have been regarded by the court as highly improper even in the absence of statute.

8o. State $c x$ rel. Williams v. Whitman, I16 Fla. 196, I56 So. 705 (1934).

81. State v. Striggles, 202 Iowa I318, 210 N. W. I37 (I927).

82. People v. O'Brien, 96 Cal. 171, 176, 31 Pac. 45,47 (I892).

83. Holmes, The Common Law (I88I) 48.

84. Any possible difficulties of proof as to whether the citizen acted in reliance upon the decision should be solved by a presumption of such reliance-perhaps even the so-called "conclusive presumption". Sce State v. O'Neil, 147 Iowa 513, 523, 126 N. IV. 454,457 (1910). 
sions of a statute, the meaning of which is clear ${ }^{85}$ or has been judicially determined; it is quite a different matter to require each person to predict, at his peril, the exact meaning which will be assigned by the court to an enactment which is ambiguous or obscure. If the meaning of a statute is not clear, and has not been judicially determined, one who has acted "in good faith" should not be held guilty of crime if his conduct would have been proper had the statute meant what he "reasonably believed" it to mean, even if the court should decide later that the proper construction is otherwise. ${ }^{86}$

\section{Specific Intent}

More common, factually, than exceptions of the types heretofore mentioned, are those recognized in cases in which some special mental element, required for conviction of the particular offense, is found to be wanting because of ignorance of the law. Thus, the maxim is held not to apply where "specific intent is essential to a crime, and ignorance of law negatives the existence of such intent". ${ }^{87}$ This exception has been quite generally recognized in prosecutions for larceny and the associated offenses of robbery and embezzlement. The actus reus of the crime of larceny is the trespassory taking and carrying away of the personal property of another. This may be done intentionally without committing larceny, as where a chattel is wrongfully taken for a temporary use with the intent to return it to the owner. ${ }^{88}$ In other words the mental element required for guilt of larceny is not merely the intent to do the actus reus, but the intent to steal一the animus furandi. ${ }^{89}$ The same mental element is required for robbery..$^{90}$ An intent to take a chattel which the taker bona fide believes is his property which is being held wrongfully by another, does not constitute animus furandi, however erroneous the belief may be. ${ }^{91}$ Hence one who takes and carries away the chattel of another under such a bona fide belief is not guilty of

85. "The law, which the respondents are conclusively presumed to have known, as applicable to their case, is well settled and free from all obscurity or doubt." State v. Goodenow, 65 Me. 30 (1876).

86. Cutter v. State, 36 N. J. L. 125 (1873) ; Burns v. State, r23 Tex. Cr. R. 6r I, $6 \mathrm{I} \mathrm{S.} \mathrm{W.} \mathrm{(2d)} 5 \mathrm{I} 2$ (I933). For the quotations in the text see id. at 6I5, 6I S. W. (2d) at $5 \mathrm{I} 4$. 1929).

87. United States v. One Buick Coach Automobile, 34 F. (2d) 3 I8 (N. D. Ind.

88. ". . . if the property were taken with the intention of only using it temporarily and then returning it to the owner, it is not larceny. . ." State v. Davis, 38 N. J. I. I76 (1875). See also Rex v. Crump, I C. \& P. 658, I7I Eng. Rep. R. I357 (IS25).

89. State v. Ryan, 12 Nev. 401 (1877).

90. "To constitute robbery the taking must in all cases be accompanied with a felonious intent, or animus furandi." Johnson v. State, 24 Okla. Cr. R. 326, 330, 218 Pac. 179, I8I (1923).

91. Rex v. Knight, 2 EAST, Pleas of the CRown * 510 ; Morningstar v. State, 55 Ala. I48 (1876); Brown v. State, 28 Ark. 126 (1873). 
larceny, even if his error was due to ignorance of law. ${ }^{\mathbf{9 2}}$ For the same reason, such a taking, accomplished by means of force or menaces, is not robbery; ${ }^{93}$ and an attempt to take by such means and under such belief does not constitute an assault with intent to commit robbery. ${ }^{94}$ The taker's ignorance of law does not excuse his deed. He is answerable for trespass in either of the first two cases, ${ }^{95}$ although this of itself is not a crime; ${ }^{96}$ and he would be guilty of assault in the second and third. ${ }^{97}$ But in each case he is saved from conviction of the offense charged for the simple reason that one of the elements required for guilt has been disproved. Needless to say guilt would be established even in such a case if defendant's knowledge of law was conclusively presumed, but this is one of the recognized exceptions and the presumption is not conclusive at this point.

The crime of embezzlement, created by statute in England to fill certain gaps in the law of larceny, ${ }^{98}$ also includes a specific intent. ${ }^{99}$ This intent, while perhaps not strictly an intent to steal, is an intent to deprive the owner of his property and is for practical purposes the counterpart of the animus furandi required for larceny. ${ }^{100}$ Hence the unauthorized retention of the property of another under a bona fide claim of right is not embezzlement even if the error is one of law. ${ }^{101}$

Certain offenses are not committed unless the prohibited deed is done fraudulently. Without attempting to exhaust the list it may be mentioned that this is true of such common law offenses as forgery

92. Morningstar v. State, 55 Ala. 148 ( 1876 ) ; State v. Sawyer, 95 Conn. 34, Iro Atl. $46 \mathrm{Y}$ (I920); People v. Schultz, 7I Mich. 315, 38 N. W. 868 (I888); see Territory v. Dowdy, I4 Áriz. 145, I47, I24 Pac. 894, 895 (I912). One may be properly convicted of larceny of goods although he claims to own them if the claim is not made in good faith. Bridgeman v. State, I45 Ark. 554, 225 S. W. I (I920) ; Morrisette v. State, 77 Ala. 71 (I884); State v. Carroll, 160 Mo. 368, 60 S. W. I087 (I900).

93. Rex v. Haill, 3 C. \& P. 409, 172 Eng. Rep. R. 477 (1828); Brown v. State, 28 Ark. I26 (I873) ; State v. Hollyway, 4I Iowa 200 (I875); Johnson v. State, 24 Okla. Cr. R. 326, 218 Pac. 179 (I923) ; People v. Hughes, II Utah I00, 39 Pac. 492 (I895).

94. Barton v. State, 88 Tex. Cr. R. 368, 227 S. W. 317 (I922).

95. Morrisette v. State, 77 Ala. 71,74 (1884); State v. Hollyway, $4 \mathrm{r}$ Iowa 200, 202 (I875); cf. State v. Sawyer, 95 Conn. 34, Iro Atl. 46r (I920).

96. The word "trespass" is sometimes used in the older writings to mean misdemeanor in distinction from felony. I Brshop, NEw CrImINal LAW (8th ed. I892) $\$ 625$. Such a taking would not be a "trespass" in this sense, but the better usage limits the word "trespass" to the civil wrong except in certain instances such as malicious trespass to real estate.

97. Defendant took two bales of cotton from another at the point of a gun. $\mathrm{He}$ did this in the presence of a crowd of persons, including a peace officer, under a claim of title. In reversing a conviction of robbery the court said defendant's conduct "was quite reprehensible and merited punishment." Brown v. State, 28 Ark. I26, 129 (1873).

98. See Kenny, Outhines of Criminal Law (I5th ed. I929), c. I4.

99. Certain types of embezzlement statutes do not require any intent other than to do the prohibited deed itself. See, for example, Hunter v. State, I58 Tenn. 63, I2 S. W. (2d) $36 \mathrm{r}$ ( 1928 ).

100. See 2 Brshop, op. cit. supra note $96, \$ \S 379,47 \mathrm{r}$.

I0r. Lindgren v. United States, 260 Fed. 772 (C. C. A. gth, I9r9); People v. Lapique, I20 Cal. 25, 52 Pac. 40 (I898); Eatman v. State, 48 Fla. 21, 37 So. 576 (I904); Taylor v. Commonwealth, II9 Ky. 73I, 75 S. W. 244 (I903). 
and uttering a forged instrument, ${ }^{102}$ and of certain statutory offenses such as some of those included in the penal provisions of the bankruptcy act, ${ }^{103}$ and fraudulent conveyances in states in which these have been made crimes. ${ }^{104}$ As fraudulently means an "intent to defraud", there is here a requirement of a special attitude of mind in the nature of an "intent" in the true sense of the word. And a mistake of law may be of such a nature as to indicate that a certain deed was not done fraudulently, although this element would have been present had the same thing been done without such a mistake. Even one who obtains money or chattels from another by wilful misrepresentations is not guilty of the crime of obtaining property by false pretenses if he honestly believes he is entitled to exactly what he gets, although a misunderstanding of the law may be the basis of his erroneous notion. ${ }^{105}$ Such a one is not entirely above reproach because he intentionally makes false statements to influence the action of another. But his conduct is not fraudulent because he seeks only to have that done which he sincerely believes should be done. In a different type of offense his mistake of law might result in conduct, actually improper, but performed in the utmost good faith in every sense of the word. It would be an obvious contradiction in terms to speak of such conduct as "fraudulent".

\section{Special Mental Element Other than Intent .}

A special mental element required for guilt of some particular offense may be other than an intent in the true sense of the word. Common illustrations involve offenses in which the additional requirement is that the deed be done (I) maliciously, (2) corruptly, (3) wilfully or (4) knowingly. And in certain cases ignorance of law may negative the existence of such an element.

Maliciously. A bona fide belief in the lawfulness of what was done, although erroneous, was held to be a defense to a prosecution for maliciously setting fire to a furze, ${ }^{106}$ maliciously removing rails from a fence, ${ }^{107}$ maliciously tearing down a fence, ${ }^{108}$ maliciously removing scales and a partition from a building, ${ }^{109}$ and maliciously removing crops from the field of another. ${ }^{110}$ As previously mentioned, mistake

I02. Regina v. Parish, 8 C. \& P. 94, I73 Eng. Rep. R. 413 (1837).

I03. National BankRuptcy Act, $\$ 29$ (a) and (b), 30 Stat. 554 (I898), ir U. S.

C. A. $\$ 52$ (1927).

I04. See, for example, Mo. Stat. Ann. (Perm. ed. I932) c. 30, § 4098.

105. Rand v. Commonwealth, 176 Ky. 343, 353, I95 S. W. 802,808 (I9I7).

106. Regina v. Twoze, I4 Cox C. C. 327 (1879).

107. Goforth v. State, 8 Humph. 37 (Tenn. I847).

I08. Palmer v. State, 45 Ind. 388 (1873).

109. State v. Newkirk, 49 Mo. 84 (I87I).

IIO. State v. Luther, 8 R. I. I5I (1865). The statute in this case did not use the word "maliciously" or any other word of like import, but the court held that it must be implied. 
of law will not excuse homicide, but the possibility of its being sufficient under some circumstances to negative the existence of malice aforethought (so that the slaying will be manslaughter only) should be recognized. If the court does not take this position the jury will probably reach the same result by applying its own common sense, ${ }^{111}$ but it would be wiser as well as more sound to state the law in these terms: while mistake of law will not excuse homicide it may in a particular case be such a mitigating circumstance as to reduce the grade of the offense to manslaughter.

Corruptly. For conviction of certain offenses there is a specific requirement that the prohibited deed be done corruptly, and this adverb may not properly be applied to what is done with a bona fide belief of propriety, even if such belief is induced by ignorance of law. Perjury, for example, is not merely swearing to that which is really not the fact, but doing this wilfully and corruptly. ${ }^{112}$ Hence one who testified that no partnership existed between himself and another, was held not to be guilty of perjury although a legal relation of this nature actually existed, if he gave his testimony in good faith reliance upon the advice of counsel that the dealings between the two did not as a matter of law create a partnership. ${ }^{113}$ Conviction of perjury was reversed in another case because the defendant was not permitted to explain his misstatement in the light of his erroneous understanding of the legal title to certain property and the extent of the exemption of the homestead law. ${ }^{114}$

Another illustration is in the field of extortion. To be guilty of this offense at common law the officer must have "wilfully and corruptly demanded and received other or greater fees than the law allows." 115 And this additional mental element has frequently been held to be implied in statutes which do not include the word "corruptly". ${ }^{116}$ Where this element has been overlooked (by the legislature or the court) it has been held no defense to a charge of extortion that the officer honestly believed he was entitled to the fee which he charged; ${ }^{117}$ but where this very sound requirement has been recognized, a misunder-

III. In People v. Cook, 39 Mich. 236 (1878); and Weston v. Commonwealth, III $\mathrm{Pa}$. 25I, 2 Atl. Igr (1885), the courts did not suggest that a bona fide belief, resulting from a mistake of law as to the right to use deadly force to prevent crime or to defend property, would negative malice aforethought, but although the charges were murder, the verdicts were guilty of manslaughter.

II2. Rex v. Smith, 2 Shower K. B. I65, 89 Eng. Rep. R. 864 (I68I).

II3. State v. McKinney, 42 Iowa 205 (1875).

II4. State v. Lazarus, I8I Iowa 625, I64 N. W. I037 (I9I7).

II5. Runnells v. Fletcher, I5 Mass. 525 (I8I9).

II6. Leeman v. State, 35 Ark. 438 (1880); State v. Pritchard, I07 N. C. 921 , 12 S. E. 50 (1890).

II7. Levar v. State, I03 Ga. 42, 29 S. E. 467 (I897); Commonwealth v. Bagley, 7 Pick. 279 (Mass. I828); People v. Monk, 8 Utah 35, 28 Pac. I I 5 (I892). 
standing of the law which induced a bona fide belief in the lawfulness of the charge made, has been held to establish innocence. ${ }^{118}$

If an officer, under color of his office, illegally and corruptly inflicts upon a person any bodily harm, imprisonment, or injury other than extortion he is guilty of the offense of oppression. ${ }^{110}$ Because of . the special requirement of corruptness a magistrate who commits a person under a bona fide mistake of law is not guilty of a crime. ${ }^{120}$ As it was said by an English court, "When magistrates act uprightly and honestly, even though they mistake the law, no information ought to be granted against them." 121

Misconduct in office is not a crime unless the violation or neglect of duty is wilful, corrupt or fraudulent; ${ }^{122}$ hence an honest belief of propriety though based upon a mistake of law, has been held to bar a conviction of wilfully and corruptly granting a tavern license, ${ }^{123}$ or neglecting an official duty. ${ }^{124}$

Wilfully. "The word 'willful' . . . is elastic and is of somewhat varied signification according to the context in which it is found and the nature of the subject matter to which it refers." 125 At times it may mean no more than a willingness to do the particular deed, ${ }^{126}$ but in certain connections it has been held to mean "not merely 'voluntarily', but with a bad purpose." 127 Its import in one case was given as "corruptly, with fraudulent intent, designedly and with improper motives." 128 Of particular interest in the present discussion is the requirement often imposed because of the use of the word "wilful", that the act be done, not only with an evil intent, but also "without reasonable grounds for believing the act to be lawful'. ${ }^{129}$

118. United States v. Highleyman, 26 Fed. Cas. No. 15,36I (W. D. Mo. 1876); Cleaveland v. State, 34 Ala. 254 (I859); Leeman v. State, 35 Ark. 438 ( I880); Cutter v. State, 36 N. J. L. 125 (Sup. Ct. I873); State v. Pritchard, I07 N. C. 921, I2 S. E. 50 (I890); Burns v. State, I23 Tex. Cr. R. 6II, 6I S. W. (2d) 512 (I933); Haynes v. Hall, 37 Vt. 20 (I864).

II9. United States v. Deaver, 14 Fed. 595 (W. D. N. C. I882). Statutes sometimes speak in terms of "wilful and malicious oppression" to incorporate the special mental element. Mo. Rev. Stat. (I929) c. 30, \$3945; State v. Kruger, 280 Mo. 293, 217 S. W. 310 (Igrg).

120. Regina v. Badger, 4 Q. B. 468 , I14 Eng. Rep. R. 975 (I843).

I2I. Rex v. Jackson, I Term. R. 653, 99 Eng. Rep. R. I302, I303 (1737).

122. State v. Boyd, I96 Mo. 52, 94 S. W. 536 (I906). Some statutes seem not to require this mental element. State v. Browne, 4 Idaho 723, 44 Pac. 552 (I896).

123. People v. Jones, 54 Barb. 3II (N. Y. I863). Defendants are not guilty of this charge unless they "knowingly and purposely disregarded the statute". Id. at 3I8.

124. State v. Bair, 7I Ohio St. 4I0, 73 N. E. 5 I4 (I905).

125. County Canvassing Board v. Lester, 96 Fla. 484,489 , i I8 So. 201, 202 (1928). I26. See People v. O'Brien, 96 Cal. 17I, 176, 31 Pac. 45, 47 (1892); Commonwealth v. Robinson, $305 \mathrm{~Pa}$. 302, 308, I57 Atl. 689, 692 (I931).

127. Felton v. United States, 96 U. S. 699, 702 (I877).

128. State v. Lazarus, I81 Iowa 625, 634, I64 N. W. I037, 1040 (I917).

129. See King v. State, 103 Ga. 263, 265, $30 \mathrm{~S}$. E. 30, 3I (1898); Smythe v. State, 5I Tex. Cr. R. 408, 4I5, 103 S. W. 899, 903 (I907); Bennett v. State, ro9 Tex. Cr. R. 237, 239, 4 S. W. (2d) 62, 63 (I928). There is this slight variation in the actual quotations in the three cases, in this order: ( 1 ) without ground, etc., (2) without reasonable ground, etc., (3) without reasonable grounds, etc. 
One who cuts timber from the land of another without proper authority is liable in a civil action for trespass even if he in good faith thinks the land is his own; ${ }^{130}$ but if a statute has provided a criminal penalty for one who revilfully commits such a trespass, he is not guilty of this offense. ${ }^{131}$ And one who has without protest crossed the land of another by a certain way for fifteen years and continues such practice after the other attempts repeatedly to close that way, is not guilty of wilful trespass under the statute if he in good faith believes that his long use gives him a license to cross there, even if the law of the state requires a longer period for this purpose. ${ }^{\mathbf{1 3 2}}$

In certain other offenses also, the use of the word "wilful" may add to the crime a special mental element of such a nature that a misunderstanding of the law may result in a bona fide belief of propriety sufficient to negative criminal guilt. On this ground a voter who cast his ballot in good faith in the ward in which he ate his meals was held not guilty of wilfully voting where he was not entitled to vote, although he should have voted in another ward in which the room where he regularly slept was situated. ${ }^{133}$ And one who exercised the functions of an office beyond the proper limit, but under the bona fide belief that he was lawfully entitled to do so, was held not guilty of wilful usurpation of office. ${ }^{134}$

One under examination in a federal tribunal may not refuse to answer on account of probable incrimination under state law. This point was not definitely settled until the first of the Murdock cases was decided. ${ }^{135}$ Prior to this decision one Murdock had refused to give testimony as to deductions claimed in his 1927 and 1928 income tax returns on the ground that his answers would tend to incriminate him under state law. After this decision he was indicted for wilfully failing to supply information for the computation of his tax, the indictment being based upon his refusal to give the desired testimony. In reversing the conviction the court pointed out that a failure to do what is required is not "wilful" if it is due to a bona fide misunderstanding of the law. ${ }^{136}$

130. State v. Shelvin-Carpenter Co., I02 Minn. 470, II4 N. W. 738 (1908).

I3I. Hateley v. State, II 8 Ga. 79, 44 S. E. 852 (1903). The Minnesota case in the preceding note held that if the trespasser acted under a bona fide claim of right he is not liable for punitive damages as a wilful trespasser, even if his mistake was one of law.

132. State v. Hause, 7I N. C. 518 (I874); see Wiggins v. State, IIg Ga. 216, 46 S. E. 86 (1903).

133. State v. Savre, 129 Iowa 122, 105 N. W. 387 (I905). But see People v. Becker, I79 Ill. App. 446, 453, 454 (1913).

134. People v. Bates, 79 Hun 584, 29 N. Y. Supp. 894 (Sup. Ct. I894). The same result has been reached under a statute which did not use the word "wilfully". Kreidler v. State, 24 Ohio St. 22 (I873). Contra: Wayman v. Commonwealth, I4 Bush 466 (Ky. I879).

I35. United States v. Murdock, 284 U. S. I4I (193I).

136. United States v. Murdock, 290 U. S. 389 (1933). 
Knowingly. The word "knowing" in a criminal statute may add a mental element to the particular offense which will be negatived by ignorance or mistake of some other law. It was very properly held, for example, that one who cast his ballot in good faith and upon advice of competent counsel was not guilty of the statutory offense of voting "knowing himself not to be a legal voter" even though the advice was erroneous. ${ }^{137}$ An officer who receives a fee to which he is not entitled, while acting under the bona fide belief that the fee is legally due, is not guilty under a statute which provides a penalty for an officer who shall "knowingly" receive a fee to which he is not entitled. ${ }^{138}$ And it is error to instruct that ignorance of the law is no excuse to a charge of wilfully and knowingly attempting to evade the payment of income taxes. ${ }^{139}$

\section{Ignorance or Mistake of What Law}

Where an exception to the maxim is recognized because of bona fide reliance upon (I) a statute thereafter held to be unconstitutional, (2) a decision subsequently overruled, or (3) erroneous legal advice by a commission or officer authorized by law to advise the public upon such a matter, the mistake may be with reference either to the very law violated or to some other law, as in the Murdock case mentioned above. The same is true in case of bona fide misinterpretation of an obscure or ambiguous statute not at the time clarified by judicial decision. If none of these grounds is present and an exception is claimed solely on the absence of a required specific intent or other special mental element because of ignorance or mistake of law, the error must relate to some law other than that under which the prosecution itself is brought. This may be tested by reference to the types of cases already mentioned. In a larceny case it may be shown that a misunderstanding of property law led to the bona fide belief that the particular chattel belonged to the defendant and that he had a lawful right to immediate possession thereof, but not that he never heard of the law of larceny or that he mistakenly believed that he could take away and appropriate another's property under the particular circumstances without subjecting himself to the penalty of that law. ${ }^{140}$ In a prosecution for malicious trespass

137. Commonwealth v. Bradford, 9 Metc. 268 (Mass. I845). But cf. State v. Boyett, 32 N. C. 336 (1849).

138. Cleaveland v. State, 34 Ala. 254 (1859) ; United States v. Highleyman, 26 Fed. Cas. No. 15,36r (W. D. Mo. 1876).

139. Hargrove v. United States, 67 F. (2d) 820 (C. C. A. 5th, I933).

140. A customary practice of appropriating property of others without consent is not a defense to a charge of larceny. Commonwealth $v$. Doane, I Cush. 5 (1848). As to embezzlement, see Lewis y. People, 99 Colo. 102, 118, 60 P. (2d) 1089, 1097 (1936) ; Stumberg, Mistake of Law in Texas (1937) I5 TEx. L. Rev. 287, 290. 
based upon removing a fence from a certain path, it could be shown that a mistaken belief with reference to the law of right of way led to the opinion that the fence should not be there, but not that defendant did not know there was a penalty for wrongfully tearing down another's fence. In a prosecution for extortion, in a jurisdiction in which the element of corruptness is recognized as a requirement for guilt, the officer can show his misunderstanding as to the fees allowed by law, but not his belief that unauthorized fees could be collected without committing a crime. And under a charge of voting "knowing himself not to be a legal voter" the defendant could show his misunderstanding of the election law, but not his ignorance of the penalty provided for casting a ballot improperly. In the last case both provisions might appear in the same statute, but the want of knowledge which is admissible in evidence is limited to those clauses which determine who is entitled to vote and where, and does not extend to the penal clause itself.

\section{Good Faith and Reasonable Grounds}

A "dishonest pretense" of ignorance or mistake of law will never be recognized as disproving guilt of crime. ${ }^{141}$ Because of this fact, in all of the exceptional situations in which ignorance or mistake of law will be recognized for this purpose there is a requirement worded in such terms as that defendant must have been "acting in good faith", ${ }^{142}$ or in the "bona fide belief" 143 or "honest belief" 144 that the law was different from what it really is. In addition to this requirement, which is present in all of the cases, ${ }^{145}$ it is sometimes required that this sincere belief be based upon reasonable grounds.

If the offense charged is one requiring a specific intent in the true sense of intention, guilt may be disproved by an honest belief inconsistent with such an intent, even if the belief results from a mistake of law not based upon reasonable grounds. ${ }^{146}$ In other words a belief may be very sincere although not very reasonable. Hence one who carries away the chattel of another in the honest belief of a lawful right to do so is not guilty of larceny, even if the ground for his belief is

' I4r. State v. Carroll, I60 Mo. 368,60 S. W. I087 (Igor). See also Morrissette v. State, 77 Ala. 71 (I884); Bridgeman v. State, I45 Ark. 554, 225 S. W. I (1920).

I42. Burns v. State, I23 Tex. Cr. R. 6II, 615, 6I S. W. (2d) 5I2, 514 (I933).

I43. State v. Hollyway, 4I Iowa 200, 202 (I875). ". . . bona fide believing. . . Johnson v. State, 24 Okla. Cr. R. 326, 330, 2I8 Pac. I79, I8I (I923).

I44. Rand v. Commonwealth, I76 Ky. 343, 353, I95 S. W. 802,808 (I9I7). ". . if the defendant honestly thought. . ." Commonwealth v. Brisbois, 28I Mass. $125,128,183$ N. E. I68, I69 (1932).

145. See the cases cited in the three preceding notes.

146. If property is taken "under an honest, although groundless, claim of right", it is not larceny. Territory v. Dowdy, I4 Ariz. 145, I47, I24 Pac. 894, 895 (1912). A study of the other larceny cases cited in this chapter will disclose a total want of any insistence that the ignorance or mistake of law be reasonable. 
"weak"; ${ }^{147}$ and one who appropriates money which he had collected for another is not guilty of embezzlement "however mistaken . . . or ill founded his claim of right might in fact be, if he honestly entertained such a belief." 148 The jury is not bound to accept the defendant's statement that he believed he had a lawful right to do as he did, ${ }^{149}$ and the absence of reasonable grounds for the alleged belief may be considered by them in determining whether he "honestly believed" he had such a right or is merely resorting to a "pretext". ${ }^{150}$

If for guilt of the offense charged there is required some special mental element other than a specific intent in the true sense of the word, the question whether a mistake of law not based upon reasonable grounds could disprove guilt seems to depend upon the peculiarities of this special element. For example, there are numerous indications in the cases that ignorance or mistake of law will not disprove the charge of "wilfully" doing the prohibited deed unless the ignorance or mistake was based upon reasonable grounds. ${ }^{151}$

In prosecutions in which ignorance or mistake of law is interposed as a defense on some ground other than to disprove the existence of some required specific intent or other special mental element the problem will seldom arise. The receipt of legal advice from a commission or officer authorized by law to advise the public upon such a matter is good ground for the citizen to believe the advised course of action is lawful. And the mere existence of a statute not yet held unconstitutional or a decision not yet overruled is good ground for the citizen to believe it is law. Furthermore it should be presumed that he acted with knowledge of such statute or decision, ${ }^{152}$ the same as any other.

On the other hand, if the defense is that the statute was ambiguous or obscure and its meaning had not been settled by judicial decision at the time of the alleged offense, the defendant may properly be required to show that he "reasonably believed" it to have the meaning he attributed to it as well as that he did so believe "in good faith". ${ }^{153}$

I47. Morningstar v. State, 55 Ala. I48, I49 (I876).

I48. Eatman v. State, 48 Fla. 21, 29, 37 So. 576,579 (1904).

149. Commonwealth v. Brisbois, 28r Mass. 125, 183 N. E. 168 (1932).

I50. Morningstar v. State, 55 Ala. 148, I49 (1876).

I51. One of the common definitions of "wilful" (where the whole context requires more than merely intentional conduct) is an evil intent "without reasonable grounds for believing the act to be lawful". This is found with slight variations in wording, in King v. State, 103 Ga. 263, 265, 30 S. E. 30, 31 (I898) ; Smythe v. State, 51 Tex. Cr. R. 408, 4I5, 103 S. W. 899 , 903 (I907) ; Bennett v. State, I09 Tex. Cr. R. 237, 239, 4 S. W. (2d) 62,63 (1928).

152. See State v. O'Neil, I 47 Iowa 513, 523, 126 N. W. 454, 457 (1910).

I53. Burns v. State, I23 Tex. Cr. R. 6I I, 6I5, 6I S. W. (2d) 512, 514 (1933). 


\section{II}

\section{IgNoRANCE or Mistake of FaCt}

\section{In General}

Ignorance or mistake of fact is very often an excuse for what would otherwise be a crime. A street car conductor, for example, who forcibly ejects a passenger from the car under the honest and reasonable (though mistaken) belief that his fare has not been paid, is liable to the passenger in a civil action but not guilty of criminal assault and battery. ${ }^{154}$ Other examples of mistakes of fact sufficient to disprove a charge of assault and battery, include such cases as that of the railroad employee who forcibly removed from the platform one who was there as a passenger but was believed to be there for an unlawful purpose $;{ }^{155}$ the police officer who arrested a person for being intoxicated on a public street, mistakenly believing him to be drunk; ${ }^{156}$ and the householder who wounded a member of a crowd thought to be making a felonious assault upon the dwelling at night, although the shots by members of the crowd were fired, not at the house, but only in the spirit of frolic. ${ }^{157}$ In addition there are numerous cases recognizing mistake of fact as an excuse in prosecutions for other offenses. ${ }^{158}$

"Ignorantia facti excusat","159 however, is obviously too sweeping even for a general statement of law, because it is clear (to mention only one point for the moment) that if a certain deed would constitute exactly the same crime under either of two factual situations, it will be no excuse that one was mistaken for the other. ${ }^{160}$ Hence some modification is needed, such as that "in some cases ignorantia facti doth excuse", ${ }^{161}$ or "an honest mistake of fact will generally shield one from a criminal prosecution." 162 To be more specific, it may be stated as a

I54. State v. MicDonald, 7 Mo. App. 5ro (I879).

I55. Commonwealth v. Power, 7 Metc. 596 (Mass. I844).

I56. Commonwealth v. Presby, I4 Gray 65 (Mass. I860).

I57. State v. Nash, 88 N. C. 6I8 (I883).

I58. Carrying concealed weapons: Miles v. State, 52 Tex. Cr. R. $56 \mathrm{I}$, ro8 S. W. 378 (I908). See also State v. Williams, I84 Iowa 1070, I69 N. W. 371 (I918). Embezzlement: State v. Smith, 47 La. Ann. 432, 16 So. 938 (1895); Commonwealth v. Wiison, $266 \mathrm{~Pa} .236$, 109 Atl. 913 (I920). Forgery: Scott v. State, 9I Miss. I56, 44 So. 803 (1907) ; Crossland v. State, III Tex. Cr. R. 357, I2 S. W. (2d) 1036 (I929); Rex v. Forbes, 7 C. \& P. 224, 173 Eng. Rep. R. 99 (1835). Harboring a slave: Birney v. State, 8 Ohio 230 (i837). Illegal voting: Gordon v. State, 52 Ala. 308 (I875). Larceny: Bird v. State, 48 Fla. 3, 37 So. 525 (1904); State v. Barrackmore, 47 Iowa 684 (1878). Malicious trespass: Wagstaff v. Schippel, 27 Kan. 450 (1882). Murder: Regina v. Rose, 15 Cox C. C. 540 (1884). Unzholesome provisions: State v. Snyder, $44 \mathrm{Mo}$. App. 429 ( $189 \mathrm{I}$ ). Uttering a forged instrument: United States v. Carll, I05 U. S. 6II (I88I). Nonzilfull intoxication: State v. Brown, 38 Kan. 390, I6 Pac. 259 (1888).

I59. Farrell v. State, 32 Ohio St. 456,459 (1877).

I60. Regina v. Lynch, I Cox C. C. 36ז (1846).

i6i. I Hale, Pleas of the Crown 42.

I62. People v. Cohn, 358 Ill. 326, 33I, I93 N. E. I50, I53 (1934). 
general rule (subject, however, to exceptions in certain cases ${ }^{163}$ ) that mistake of fact will disprove a criminal charge if the mistaken belief is (a) honestly entertained, (b) based upon reasonable grounds and (c) of such a nature that the conduct would have been lawful had the facts been as they were reasonably supposed to be. ${ }^{164}$

\section{Honest and Reasonable Belief}

The term "honest belief", and equivalent phrases, ${ }^{165}$ are sometimes used to express two different ideas: (I) that the belief must have been sincere and (2) that what was done would have been proper had the facts been as they were mistakenly supposed to be. ${ }^{166}$ It will be more convenient, however, to deal with these matters separately, and the second will be reserved for subsequent attention. As to the first no more need be said than that the possibility of excuse based upon mistake of fact never has any application "where there is no honest belief . . . but . . . a dishonest pretense is resorted to in the endeavor to escape punishment." ${ }^{167}$ The mistaken belief must always be "honest and real" rather than "feigned"; 168 sincere rather than a mere "pretext". ${ }^{169}$

While there is no exception to the requirement that the mistaken belief of the factual situation must be genuine, the question whether it must be based upon reasonable grounds is not so simple. Undoubtedly the second requirement is frequently present, as indicated by the repeated occurrence of such phrases as "reasonable grounds", 170 "wellgrounded", 171 "reasonable ground for believing", 172 "due care to ascertain", 173 "might reasonably have been expected to induce such a belief in a man of ordinary firmness and intelligence", 174 "not superinduced

163. In certain cases the statement requires too much, in certain other cases it is inadequate. See infra.

I64. See Regina v. Tolson, 23 Q. B. D. I68, I90 (I889) ; Marmont v. State, 48 Ind. $2 \mathrm{I}, 3 \mathrm{I}$ (I874).

I65. Such as "bona fide belief". Mulreed v. State, I07 Ind. 62, 66, 7 N. E. 884, 887 (1886).

166. "Ignorance or mistake in fact, guarded by an honest purpose, will afford, at common law, a sufficient excuse for a supposed criminal act." Farrell v. State, 32 Ohio St. 456,459 (1877).

167. State v. Carroll, i60 Mo. 368, 371, 60 S. W. 1087, 1088 (1900).

I68. Dotson v. State, 62 Ala. I4I, I44 (1878).

I69. Barton v. State, 88 Tex. Cr. R. 368, 370, 227 S. W. 317, 318 (I92I).

170. Hale y. Commonwealth, 165 Va. $808,813,183$ S. E. I80, I82 (1936).

I7I. State v. Rhone, 223 Iowa I22I, 1233, 275 N. W. 109, 116 (1937).

172. Shorter v. People, 2 N. Y. 193, 197 (1849); State v. Nash, 88 N. C. 618, 621 (1883). ". . . reasonable ground to believe. . ." Marmont v. State, 48 Ind. 2I, 3I (I874).

I73. Mulreed v. State, I07 Ind. 62, 66, 7 N. E. 884, 887 (1886). “. . . proper care to ascertain. . ." Welch y. State, 46 Tex. Cr. R. 528, 530, 81 S. W. $50,5 \mathrm{I}$ (1904). "He is bound to exercise reasonable diligence to ascertain the facts. . " " Gordon v. State, 52 Ala. 308, 310 (I875).

174. State v. Cook, 78 S. C. 253,264 , 59 S. E. 862,866 (1907). 
by fault or negligence", ${ }^{175}$ or "it must also be such a mistake as does not arise from a want of proper care". ${ }^{176}$

If no specific intent or other special mental element is required for guilt of the offense charged, a mistake of fact will not be recognized as an excuse unless it was based upon reasonable grounds. ${ }^{177}$ One, for example, who kills another because of a mistaken belief that his own life is in imminent peril at the hands of the other, is not excused if there is no reasonable ground for this belief. ${ }^{178}$ If a specific intent or other special mental element is required for guilt of the offense charged, the possibility of excuse due to a mistake of fact not based on reasonable grounds must be studied in the light of this special requirement and the mistake itself. The ultimate question in any prosecution is whether or not all of the essential elements of guilt are established. If any such element is found to be wanting, guilt has not been substantiated; and hence if proof of a mistake of fact, even without the support of reasonable grounds, negatives the existence of such an element, it also disproves the charge itself.

This problem is essentially the same as that involved where the existence of such an element is negatived by proof of a mistake of law. The distinction is not always clear cut. An erroneous belief of ownership and right to immediate possession of a chattel, for example, may be due to misapprehension of property law or to mistaken identity of the thing itself. In another case misunderstanding of law and fact may combine. But since the result is the same if it is sought to disprove the existence of some required specific intent or other special mental element, it is not essential for the mistake to be classified as belonging to one type or the other. Because of the requirement of a specific intent

I75. Dotson v. State, 62 Ala. I4I, 144 (1878).

176. Stern v. State, 53 Ga. 229 (1874); Hamilton v. State, I $x_{5}$ Tex. Cr. R. 96, 29 S. W. (2d) 777 (I930).

I77. United States v. Thompson, I2 Fed. 245 (D. Ore. I882) ; Gordon v. State, 52 Ala. 308 (I875); Dotson v. State, 62 Ala. I4I (I878); Stern v. State, 53 Ga. 229 (1874) ; Goetz v. State, 4I Ind. I62 (1872); Mulreed v. State, I07 Ind. 62, 7 N. E. 884 (1886) ; State v. Thornhill, 188 La. 762,178 So. 343 (I938); Commonwealth v. Colandro, 23I Pa. 343, 80 Atl. 57 I (IgII); Hamilton v. State, II5 Tex. Cr. R. 96, 29 S. W. (2d) 777 (1930).

In one case of carrying concealed weapons it was held reversible error to charge the jury to acquit if they found that defendant "did not know, or could not have reasonably knozen, that the pistol was in his coat." Miles v. State, 52 Tex. Cr. R. 56r, 562 , $108 \mathrm{~S}$. W. 378 (1908). This is out of line with the decided trend of the cases unless a distinction is to be drawn between situations in which the defendant intentionally does the deed which constitutes the actus reus of the offense (being induced to do so because of the mistake which is not based upon reasonable grounds) and situations in which, because of the mistake, the doing of the deed itself was unknown to the defendant.

I78. Hill v. State, I94 Ala. II, 69 So. 94I (I9I5) ; People v. Williams, 32 Cal. 280 (I867); Kyle v. People, 2r 5 IIl. 250, 74 N. E. 146 (r905); State v. Towne, I80 Iowa 339, I60 N. W. Io (I917); State v. Allen, IIr La. I54, 35 So. 495 (I903); Loy v. State, 26 Wyo. 381 , I85 Pac. 796 (r9r9). 
to steal there is no such thing as larceny by negligence. ${ }^{179}$ One does not commit this offense by carrying away the chattel of another in the mistaken belief that it is his own, no matter how great may have been the fault leading to this belief, if the belief itself is genuine. ${ }^{180}$ And a conversion of property intrusted is not embezzlement if it was due to a mistake giving rise to a bona fide belief of authority to appropriate, whether the "belief was well founded or not". 181

A mental element required for guilt of the particular offense, other than a specific intent in the true sense of the word, may be negatived by a bona fide belief resulting from an ill-grounded mistake of fact, depending upon the peculiarity of the required element. Thus an untrue statement under oath is not wilfully and corruptly false and hence not perjury if genuinely believed to be true, however great the carelessness which induced the belief. ${ }^{182}$ Because of the similarity of this problem to that previously discussed in connection with ignorance or mistake of law, it is not necessary to give further attention to it other than to speak of the most obvious type of case in which a special mental element, other than specific intent, may be disproved by evidence of mistake of fact, whether based upon reasonable grounds or not. This is where the prosecution is for an offense the very definition of which requires knowledge of some particular matter actually unknown to the defendant.

In this connection it is important to bear in mind that the word "knowledge", as used at this point in the law, includes not only actual knowledge, but also guilty belief which corresponds with the fact, ${ }^{183}$ and even "guilty avoidance of knowledge", as where the fact would have been known had not the person wilfully "shut his eyes" in order

179. People v. Watson, I54 Misc. 667, 278 N. Y. Supp. 759 (Sup. Ct. 1935), aff'd, 245 App. Div. 838, 282 N. Y. Supp. 235 (2d Dep't I935).

I80. Regina v. Halford, II Cox C. C. 88 (I868); People v. Devine, 95 Cal. 227, 30 Pac. 378 (I892) ; Dean v. State, 4I Fla. 291, 26 So. 638 (1899); People v. Shaunding, 268 Mich. 218,255 N. W. 770 (1934); Stanley v. State, 6I Okla. Cr. R. 382, 69 P. (2d) 398 (1937).

I81. Lewis v. People, 99 Colo. 102, II7, 60 P. (2d) 1089, I0g6 (1936). See also People v. Parker, 355 IIl. 258, 189 N. E. 352 (1934); Commonwealth v. Wilson, 266 Pa. 236, 109 At1. 913 (1920). In the Parker case the court speaks of "reasonable grounds", but this seems to have been an inadvertent use of the familiar phrase because the holding is that guilt is disproved by a bona fide belief of the right to appropriate certain funds "even if the claim of the defendant was ill-founded or without merit". In the $W$ ilson case the court reverses a conviction for failure to instruct properly upon the question of mistake of fact. There is no suggestion of the need for "reasonable grounds".

182. United States v. Shellmire, 27 Fed. Cas. No. I6,27I (C. C. E. D. Pa. I83I) ; People v. Von Tiedeman, I20 Cal. I28, 52 Pac. I55 (I898); Commonwealth v. Brady, 5 Gray 78 (Mass. 1855).

183. Regina v. White, I F. \& F. 665, I75 Eng. Rep. R. 898 (1859) ; State v. Friend, 210 Iowa $980,987,230$ N. W. 425,429 (1930); Meath v. State, 174 Wis. 80, 83, 182 N. W. 334,335 (I92I). 
to avoid knowing. ${ }^{184}$ It does not include, however, a bona fide belief contrary to fact, even if not based upon reasonable grounds. ${ }^{185}$

One, for example, is not guilty of uttering a forged instrument with knowledge of the forgery if he actually had no doubt of its genuineness, even if he was quite negligent in not discovering its falsity. ${ }^{186}$ A charge of receiving stolen goods knowing the same to have been stolen is not established by proof of the receipt of the goods under circumstances which should have induced a belief of this fact if the defendant actually had no such belief. ${ }^{187}$ If the statute on fraudulent banking requires receipt of a deposit by a banker knozving his bank to be insolvent at the time, "mere negligence is not enough". ${ }^{188}$ In a prosecution for obtaining property by false pretenses it is reversible error to give an instruction which will permit the jury to find the defendant guilty if he was quite careless in making the untrue statementbecause he might in good faith believe the statement to be true in spite of his fault in not having a correct understanding of the facts. ${ }^{189}$ One who sends non-mailable matter through the mail without suspecting the presence of the forbidden contents is not guilty of knowingly depositing such matter in the mails even if he was negligent in not knowing. ${ }^{190}$ As said by the California court in reversing a conviction of procuring false evidence in the form of an affidavit from one who was to defendant's knowledge incapable of making an affidavit, "facts which would ordinarily suggest the inquiry are not sufficient. The jury must believe that they did in fact suggest the inquiry to the defendant." 191

\section{Offenses not Requiring Mens Rea}

At common law a public nuisance is in substance a civil wrong, although included in the general category of "crime" because for the sake of convenience, it is handled procedurally by the machinery used for criminal cases. ${ }^{192}$ Since it is not a true crime, but only an "anomalous offense", guilt is established by what is done without the normal

I84. People v. Cummings, I23 Cal. 269, 55 Pac. 898 (I899) ; State v. Lintner, I4I Kan. 505, 4I P. (2d) 1036 (1935); People v. Sugarman, 216 App. Div. 209, 216, 215 N. Y. Supp. 56, 63 (Ist Dep't I926), aff'd, 243 N. Y. 638, I 54 N. E. 637 (I926).

I85. United States v. Shellmire, 27 Fed. Cas. No. I6,27I (C. C. E. D. Pa. I83I) ; People v. Von Tiedeman, 120 Cal. 128, 52 Pac. 155 (1898) ; State v. Dunning, 130 Iowa 678 , ro7 N. W. 927 (I906) ; Commonwealth v. Wilson, $266 \mathrm{~Pa} .236$, 109 Atl. 913 (I920); State v. Pickus, 63 S. D. 209, 257 N. W. 284 (1934). 469 (1908).

r86. Carver v. People, 39 Mich. 786 (I878); Wells v. Territory, I Okla. Cr. R. 187. State v. Alpert, 88 Vt. I9I, 92 Atl. 32 (I9I4); Meath v. State, I74 Wis. 80, 182 N.W. 334 (I92I).

I88. State v. Dunning, I30 Iowa 678, I07 N. W. 927 (I906) ; State v. Tomblin, 57

Kan. 84I, 48 Pac. I44 (1897); State v. Drew, I10 Minn. 247, I24 N. W. Iogr (IgIo).

Contra: McClure v. People, 27 Colo. 358, 6r Pac. 6iz (Igoo).

I89. State v. Pickus, 63 S. D. 209,257 N. W. 284 (1934).

190. Konda v, United States, I66 Fed. 9I (C. C. A. 7th, I908).

19I. See People v. Brown, 74 Cal. 306, 310, I6 Pac. I, 3 (1887).

192. Kenny, OUthines of Criminal LAW (I5th ed. I936) 46. 
mens rea requirement. ${ }^{193}$ This seems to be the only common law exception to the rule that criminal guilt requires mens rea as well as actus reus. ${ }^{194}$ Furthermore, this mens rea requirement normally applies to statutory crimes ${ }^{105}$ as well as to common-law offenses, but it is within the legislative power to provide a penalty for the bare deed alone. ${ }^{196}$ Whether a given statute is to be construed one way or the other "is to be determined by the court, by considering the subject matter of the prohibition as well as the language of the statute". ${ }^{197}$ The nature of the penalty involved may also be an important factor in this regard, ${ }^{198}$ although not as a simple rule of thumb. An offense may have the mens $r e a$ requirement even if the only penalty is a fine, ${ }^{100}$ and may not have it although punishable by imprisonment, ${ }^{200}$ but the tendency of these provisions is to tip the scales the other way, and if a particular case is otherwise in doubt this may be the determining factor. ${ }^{201}$

There is no moral delinquency without a blameworthy state of mind, and hence if the purpose of the statute is to prevent conduct which would generally be regarded as wrong (in the light of the prevailing moral standards of the time in the jurisdiction), the element of mens rea will ordinarily be assumed to be included even if not mentioned in the enactment. ${ }^{202}$ Not all statutory offenses, however, are of this nature. In the exercise of its police power the state may prohibit, under penalty, conduct which would otherwise be quite proper, such as parking overtime in a restricted district, ${ }^{203}$ or soliciting insurance on

193. Id. at $45-6$.

194. Ibid. Some of the early cases of criminal libel came very close to the same result, although the theory seems to have been different. Rex v. Gutch, M. \& M. 432, I73 Eng. Rep. R. I214 (I829).

195. Leeman v. State, 35 Ark. 438 ( 1880 ) ; State v. Brown, 38 Kan. 390, I6 Pac. 259 (1888); see United States v. Balint, 258 U. S. 250, $25 \mathrm{I}$ (1922) ; Troutner v. State, 17 Ariz. 506, 508, I54 Pac. 1048 (1916) ; Commonwealth v. Ober, 286 Mass. 25, 30, 189 N. E. 601,605 (I934); People v. Rice, I6I Mich. 657, 664, I26 N. W. 98I, 984 (Igro). 196. Smith v. State, 7I Fla. 639, 7I So. 915 (1916); People v. Johnson, 288 III. 442, I23 N. E. 543 (I9I9); State v. Dunn, 202 Iowa II88, 2II N. W. 850 (I927); State v. Dobry, 217 Iowa 858, 250 N. W. 702 (1933); People v. Snowberger, Ir3 Mich. 86, 7I N. W. 497 (I897) ; State v. Kelly, 54 Ohio St. I66, 43 N. E. I63 (I896); State v. Whitman, 52 S. D. 91 , 216 N. W. 858 (1927) ; McKnight v. State, I7I Tenn. 574, I06 S. W. (2d) 556 (1937). Also the last four cases cited in note I95 supra.

197. MIcKnight v. State, I7I Tenn. 574, 577, 106 S. W. (2d) 556, 557 (1937). "It is a question of legislative intent, to be construed by the court." "United States v. Balint, 258 U. S. 250, 252 (I922).

198. Sayre, Public Welfare Offenses, 33 Cor. L. Rev. 55, 83 (1933).

199. Birney v. State, 8 Ohio 230 (1837).

200. United States v. Balint, 258 U. S. 250 (1922) ; State v. Dobry, 217 Iowa 858, 250 N. W. 702 (1933).

201. Compare Commonwealth v. Emmons, 98 Mass. 6 (1867) with Stern v. State, 53 Ga. 229 (1874).

202. Adultery: State v. Audette, 8I Vt. 400, 70 At1. 833 (Ig08). Bigamy: Regina v. Tolson, 23 Q. B. D. 168 (1889). Drunk in a public place: State v. Brown, 38 Kan. 390, I6 Pac. 259 (I888). Embezzlement: State v. Blue, I7 Utah 175, 53 Pac. 978 (I898). Extortion: Leeman v. State, 35 Ark. 438 (I880); State v. Pritchard, I07 N. C. 921,12 S. E. 50 (I890). Contra: Levar v. State, I03 Ga. 42, 29 S. E. 467 (1897). Uttering a forged instrument: Regina v. Page, 8 C. \& P. r22, I73 Eng. Rep: R. 425 (1837). In addition see Troutner v. State, I7 Ariz. 506, 508, 154 Pac. I048 (I916). 203. Commonwealth v. Ober, 236 Mass. 25, I89 N. E. 601 (I934). 
behalf of an insurance company which has not complied with certain statutory requirements. ${ }^{204}$ The tendency has been to construe such statutes as providing a penalty for the thing done irrespective of the state of mind of the doer, ${ }^{205}$ unless the legislature has used language indicating otherwise. ${ }^{206}$ The development along this line has so far taken a rather haphazard course, ${ }^{207}$ but it has come to be recognized that the modern complicated social order finds the need of certain prohibitions which should be classed as "civil offenses" 208 or "public torts" ${ }^{209}$ rather than "true crimes". ${ }^{210}$ "In general, offenses not requiring mens rea are the minor violations of laws regulating the sale of intoxicating liquor, impure or adulterated food, milk, drugs or narcotics, criminal nuisances, violations of traffic or motor-vehicle regulations, or of general police regulations passed for the safety, health, or well-being of the community and not in general involving moral delinquency." 211

Needless to say, the language of the particular statute must be scrutinized. The absence of such a word as "wilfully" or "knowingly" in certain sections of a statute has peculiar significance if it has been used in other portions of the same act. ${ }^{212}$ Even the legislative history

204. McKnight v. State, I7I Tenn. 574, ro6 S. W. (2d) 556 (1937).

205. McCutcheon v. People, 69 IIl. 60I (I873); People v. Johnson, 288 IIl. 442, I23 N. E. 543 (I919) ; State v. Dunn, 202 Iowa II88, 2II N. W. 850 (I934); Commonwealth v. Boynton, 84 Mass. I6o (I86I) ; Commonwealth v. Farren, 9 Allen 489 (Mass. 1864); State v. Kelly, 54 Ohio St. I66, 43 N. E. I63 (1896) ; Commonwealth v. Weiss, I39 Pa. 247, 21 Atl. Io (I89r); Commonwealth v. Hendrie, $97 \mathrm{~Pa}$. Super. 328 (I929) ; State v. Whitman, 52 S. D. 9I, 216 N. W. 858 (I927) ; State v. Gilmore, 80 Vt. 514, 68 Atl. 658 (rg08); Weich v. State, I45 Wis. 86, I29 N. W. 656 (I9II). Where the offense is merely malum prohibitum ". . . the courts have held, with very few exceptions, that, where there is nothing in the statute to indicate that scienter is an element of the offense, the knowledge or lack of knowledge of the defendant is immaterial." State v. Whitman, 52 S. D. 91, 93, 216 N. W. 858, 859 (1927). See also State v. Kelly, 54 Ohio St. I66, 179, 43 N. E. I63, I64 (1896).

206. Siegel, Cooper \& Co. v. People, 85 Ill. App. 30I (I899).

207. The divergence in the actual results of cases in this field is due partly to differences in the wording of statutes and partly to the construction placed upon such acts by the courts. Halsted v. State, 4I N. J. L. 552 (I879). See also the cases there cited.

Compare, for example, the following cases. Permitting minor to play billiards without consent of his parent or guardian: mens rea required, Stern v. State, 53 Ga. 229 (I874); not required, Commonwealth v. Emmons, 98 Mass. 6 (I867). Selling liquor to a minor: mens rea required, People v. Welch, 7r Mich. 548, 39 N. W. 747 (I888); not required, State v. Hartfiel, 24 Wis. 60 (I869). Unlawful possession of intoxicating liquor: mens rea required, State v. Cox, 91 Ore. 518, I79 Pac. 575 (19I9); not required, State v. Whitman, 52 S. D. 9I, 216 N. W. 858 (1927). Sale of adulterated milk: mens rea required, Commonwealth v. Flanelly, I5 Gray I95 (Mass. I860) ; not required (after a change in statute), Commonwealth v. Farren, 9I Mass. 489 (I864).

208. Legis., Criminal Lazo-Reclassification of Certain Offenses as Cizil Instead of Criminal (1937) I2 WIS. L. REv. 365.

209. May, The Law of Crimes (4th ed. 1938) § ro.

210. Professor Sayre distinguishes between "public welfare offenses" and "true crimes". Sayre, Public Welfare Offenses (1938) 33 CoL. L. REv. 55, 84.

2Ir. $I d$. at 83 .

212. Siegel, Cooper \& Co. v. People, 85 IIl. App. 30r (1899) ; Commonwealth v. Raymond, 97 Mass. 567 (1867) ; People v. Snowberger, II3 Mich. 86, 71 N. W. 497 (1897). 
of the provision should receive attention, because the reason for the omission of such a term is made clear if it was originally included and subsequently stricken out by amendment. ${ }^{213}$

Knowledge of the fact which brings the deed within the statutory ban is not essential to guilt of an offense having no mens rea requirement. ${ }^{214}$ Each individual acts "at his peril" 215 in this regard and if he brings about the prohibited result his ignorance or mistake of fact will not excuse him. ${ }^{218}$ This is true even if he has used due diligence in the effort to ascertain the fact, but has been misled by the fraud of another. ${ }^{217}$

Instances of conviction under particular statutes, notwithstanding ignorance or mistake of the essential fact, include such cases as possession, ${ }^{218}$ sale ${ }^{219}$ or transportation ${ }^{220}$ of intoxicating liquor; sale of oleomargarine, ${ }^{221}$ or of adulterated food or drugs; ${ }^{222}$ sales from short weights or measures; ${ }^{223}$ admitting a minor to a billiard room without written consent of his parent or guardian; ${ }^{224}$ possession of automobile with engine number altered; ${ }^{225}$ subscribing to false statements with reference to securities; ${ }^{226}$ soliciting insurance on behalf of a company not authorized to do business within the state; ${ }^{227}$ parking overtime in a restricted district; ${ }^{228}$ and exceeding the speed limit, ${ }^{228}$ among many others. ${ }^{230}$

213. Smith v. State, 223 Ala. 346, 136 So. 270 (I93I); State v. Dobry, 217 Iowa 858,250 N. W. 702 (1934).

214. Smith v. State, 223 . Ala. 346, I36 So. 270 (I93I). ". •. knowledge or lack of knowledge . . . is immaterial." State v. Whitman, 52 S. D. $91,93,216 \mathrm{~N}$. W. 858,859 (1927).

215. Commonwealth v. Emmons, 98 Mass. 6, 8 (I867) ; People v. Snowberger, II3 Mich. 86, 92, 71 N. W. 497,499 (1897) ; State v. Kelly, 54 Ohio St. 166, 180, 43 N. E. I63, I64 (I896).

216. State v. Gilmore, 80 Vt. 5I4, 68 Atl. 658 (Ig08).

217. State v. Hartfiel, 24 Wis. 60 (1869).

218. State v. Whitman, 52 S. D. 9I, 216 N. W. 858 (1927).

219. Troutner v. State, I7 Ariz. 506, I54 Pac. I048 (I916) ; Commonwealth v. Boynton, 2 Allen 160 (Mass. I86I).

220. Commionwealth v. Hendrie, $97 \mathrm{~Pa}$. Super. 328 (1929).

22r. Commonwealth v. Weiss, I39 $\mathrm{Pa}$. 247, 21 Atl. Io (I89r). Thus a conviction of serving oleomargarine at a lunch counter was upheld although defendant was a waiter, in charge of the counter, who supposed the substance to be butter. Welch v. State, I45 Wis. 86, I29 N. W. 656 (IgII).

222. Commonwealth v. Farren, 9 Allen 489 (Mass. I864); People v. Snowberger, II3 Mich. 86, 7I N. W. 497 (1897); State v. Kelly, 54 Ohio St. 166, 43 N. E. I63 $(1896)$.

223. Smith v. State, 223 Ala. 346, r36 So. 270 (1931).

224. Commonwealth v. Emmons, 98 Mass. 6 (I867).

225. People v. Johnson, 288 I1l. 442, I23 N. E. 543 (IgIg) ; State v. Dunn, 202

Iowa II88, 211 N. W. 850 (I927).

226. State v. Dobry, 217 Iowa 858, 250 N. W. 702 (1934).

227. McKnight v. State, x7I Tenn. 574, 106 S. W. (2d) 556 (I937).

228. Commonwealth v. Ober, 286 Mass. $25,30,189$ N. E. 601,602 (1934).

229. Goodwin v. State, 63 Tex. Cr. R. 140, 138 S. W. 399 (rgrr).

230. Professor Sayre in his article, Public Welfare Offenses (I933) 33 CoL. L. REv. 55, 84 (Appendix), classifies offenses not requiring mens rea (under particular statutes) into the following groups: 
A statute, it may be added, may include some mental element and at the same time exclude part of the normal requirement, if the intention to do so is clearly expressed. For example, a Massachusetts statute provided a penalty for killing a calf less than four months old with intent to sell its meat for human consumption and also for the selling of such meat. The latter clause had an additional requirement of knowledge which was omitted from the former. It was held that one who killed a calf under the specified age with intent to sell the meat for human consumption was guilty even if he did not know the animal was so young. ${ }^{231}$

\section{Mistake Only as to Extent of Wrong}

A misdeed, committed with knowledge of sufficient facts to establish its criminality, is not necessarily limited to some lower grade of offense than would otherwise be found merely because the offender was mistaken as to some fact relating only to the degree of the crime or the extent of the wrong done. ${ }^{232}$ It is submitted, for example, that the stealing of goods of such value as to constitute grand larceny is not to be forced into the category of petit larceny merely because the thief mistakenly thought them worth less than the sum required for this purpose. And the kidnaper who transports his victim from one state to another is guilty of a federal offense although mistaken as to the location of the boundary line and unaware of crossing it. ${ }^{233}$ Some types of offense require a different answer, as where the more serious crime requires a specific intent which is lacking because of the mistake of fact. ${ }^{234}$

I. Illegal sales of intoxicating liquor

(a) Sales of prohibited beverage

(b) Sales to minors

(c) Sales to habitual drunkards

(d) Sales to Indians

(e) Sales by methods prohibited by law

2. Sales of impure or adulterated food

(a) Sales of aduiterated or impure milk

(b) Sales of adulterated butter or oleomargarine

3. Sales of misbranded articles

4. Violations of anti-narcotic acts

5. Criminal nuisances

(a) Annoyances or injuries to the public health, repose or comfort

(b) Obstructions of highways

6. Violations of traffic regulations

7. Violations of motor-vehicle laws

8. Violations of general police regulations, passed for the safety, health or well-being of the community.

231. Commonwealth v. Raymond, 97 Mass. 567 (I867).

232. In the following cases, for example, it is emphasized that the known facts alone constituted an offense (although less serious than the one charged). Brown v. State, 7 Penne. I59, 74 At1. 836 (Del. 1909); Commonwealth v. Murphy, r65 Mass. 66, 42 N. E. 504 ( 1895 ).

233. United States v. Powell, 24 F. Supp. I6o (E. D. Tenn. 1938).

234. If one should unlawfully make a thrust at another intending only to poke him with what he supposed was an ordinary cane, he would not be guilty of an assault with intent to murder, even if this is found to be a deadly instrument disguised as a cane. 
In certain very extreme situations one may be convicted of a true crime although at the time of his deed he was laboring under a mistake of fact based upon reasonable grounds, and of such a nature that the thing done would not have been a crime had the facts been as he reasonably supposed them to be. These are cases in which the deed would have involved a high degree of moral delinquency even under the supposed facts, and the claim for acquittal is based, not upon the ground that defendant thought his deed was proper or lawful but only that he thought it was a type of wrongful conduct for which no criminal penalty had been provided. ${ }^{235}$ The common examples fall within the fields of statutory rape, abduction and adultery.

A man who has illicit sexual intercourse with a girl under the age of consent is guilty of statutory rape although she consented and he mistakenly believed she was older than the limit thus established. ${ }^{236}$ This is true no matter how reasonable his mistaken belief may have been, ${ }^{237}$ as in cases in which both her appearance and her positive statement indicated she was older than she was in fact, ${ }^{238}$ or in which he had exercised considerable pains in the effort to ascertain her age. ${ }^{\mathbf{2 3 9}}$ One who has illicit intercourse with a. married person is guilty of adultery even if he has no idea that the other is married.240 Violation of the abduction statute by taking a girl under a certain age from the possession of her parent or guardian without the consent of such parent or guardian and for the purpose of prostitution or concubinage, will support a conviction notwithstanding a reasonable mistake as to the age of the girl. ${ }^{241}$ And if a statute prohibits harboring a prostitute under a certain age, a mistake on this point is no defense. ${ }^{242}$

Even without the requirement of a specific intent, the thing done may be such a wholly unexpected addition to the thing intended as to permit the excuse of mistake of fact, if the thing intended did not involve too great a degree of moral delinquency. Thus one charged with the statutory offense of assaulting a peace officer while in the lawful discharge of his duties must be convicted of simple assault only if he did not know and had not been informed that the person was an officer. Baker v. State, 53 Tex. Cr. R. I4, 108 S. W. 665 (1908).

235. See State v. Houx, 109 Mo. 654, 66r, I9 S. W. 35, 37 (189r). ". . . . the act of abduction of which the prisoner was guilty, being a morally wrong act, afforded abundant proof of his criminal mind." Regina v. Tolson, 23 Q. B. D. I68, 194 (I889). 236. People v. Ratz, II5 Cal. 132, 46 Pac. 915 (I896); Heath v. State, I73 Ind. 296, 90 N. E. 310 (1909); Commonwealth v. Murphy, I65 Mass. 66, 42 N. E. 504 (I 895$)$. Assault with intent to commit rape on a girl under the age of consent: State v. Newton, 44 Iowa 45 (1876).

237. State v. Houx, 109 Mo. 654 , 19 S. W. 35 (I89r).

238. People v. Marks, I46 App. Div. II, I30 N. Y. Supp. 524 (Ist Dep't I9II).

239. Manning v. State, 43 Tex. Cr. R. 302,65 S. W. 920 (Igor).

240. State v. Anderson, I40 Iowa 445,118 N. W. 772 (Ig08); Commonwealth v. Elwell, 43 Mass. Igo (1840).

24I. People v. Dolan, 96 Cal. 315, 3I Pac. ro7 (I892) ; State v. Ruhl, 8 Iowa 447 (1859); State v. Johnson, Ix 5 Mo. $480,22 \mathrm{~S}$. W. 463 (1893). Under express provision of a few statutes a reasonable belief that the girl is over the age limit is a defense. Regina v. Packer, I6 Cox C. C. 57 (I886); Hermann v. State, 73 Wis. 248, 41 N. W. I7I (I888).

242. Brown v. State, 7 Penne. I59, 74 Atl. 836 (Del. 1909). 
It has sometimes been suggested that the reason for this result in such cases is that these are crimes which have no mens rea requirement. ${ }^{243}$ This is quite unsound and should be avoided because it will lead to very unsatisfactory results in certain cases, such as those of insanity, compulsion, and innocent mistake of fact. The latter problem has arisen most frequently in the adultery cases. If the intercourse is obviously illicit, the mistaken belief in the unmarried status of the other party is not an innocent mistake, however-well grounded it may be since the conduct falls far below the line of social acceptability even under the supposed facts. ${ }^{244}$ "In such a case there is a measure of wrong in the act as the defendant understands it, and his ignorance of the fact that makes it a greater wrong will not relieve him from the legal penalty." 245 On the other hand, in spite of some indication to the contrary, ${ }^{246}$ it is clearly established that if the intercourse follows a marriage ceremony entered into in good faith, with no thought or reason to believe that the other party is already married, it does not constitute the crime of adultery ${ }^{247}$ if it does not occur after the mistake has been discovered. ${ }^{248}$

An innocent mistake of fact is possible even in a prosecution for statutory rape, although it will be much more rare in such a case than in prosecutions for adultery. The minimum age for a valid marriage may be substantially lower than the "age of consent" provided for statutory rape. ${ }^{249}$ The latter is concerned only with illicit intercourse and hence a husband does not commit rape by having intercourse with his lawful wife even if she is below the age established for this other

243. See May, The Law of Crimes (4th ed. I938) 62, n. II7.

244. See State v. Audette, 8I Vt. 400, 403, 70 Atl. 833, 834 (I908).

245. Ibid. See quotation from Regina v. Tolson, 23 Q. B. D. I68, 194 (1889), cited supra note 235 .

246. The case commonly cited for this position is Commonwealth $\mathrm{v}$. Thompson, 93 Mass. 23 (1865). The syllabus is quite sweeping but the actual holding is that the statutory presumption of death from seven years' absence cannot be applied where the so-called "absence" was by the one who was left behind and who remained ever since in the same general vicinity. The defendant was the one not previously married, but there was no evidence that he was unaware of the facts relied upon by the woman for her assertion that she was a widow.

Cases holding that a mistake of law will not excuse in such a prosecution must be " distinguished. Owens v. State, 94 Ala. 97, Io So. 669 ( I891); State v. Goodenow, 65 Me. 30 (I876); State v. Woods, I07 Vt. 354, I79 Atl. I (1935). As to this problem see the discussion under Bigamy, infra p. 65.

It is also necessary to distinguish cases holding merely that it is unnecessary for the state to allege and prove such knowledge on the part of the defendant, such as Fox v. State, 3 Tex. App. 329 (I877). This means only that it is incumbent upon the defendant to establish the want of such knowledge. State v. Cody, III N. C. 725, I6 S. E. $408(1892)$.

247. Vaughart v. State, 83 Ala. 55, 3 So. 530 (I887) ; Banks v. State, 96 Ala. 78, II So. 404 (I89I); State v. Cutshall, I09 N. C. 764, I4 S. E. IO7 (I89I); State v. Audette, 8I Vt. 400, 70 Atl. 833 (I908).

248. Hildreth v. State, I9 Tex. Cr. R. 195 (1885).

249. Compare CODE of IowA (I935) § 1048, with id. § I2966. 
purpose. ${ }^{250}$ If a man should have intercourse with one of such age, honestly and reasonably believed by him to be his wife, although legally she was not because of her prior secret marriage to another, he would be entirely blameless. Even a mistake as to the identity of the person with whom the connection is had could be innocent in an extreme situation. "In such a case there is no offense, for none was intended either in law or morals." 251

Mens rea is requisite to guilt of such offenses but there is no specific requirement of knowledge. Hence a prima facie case of guilt is established by proof of the act of intercourse by the defendant with one under the age of consent, or married to another, without either averment or proof of any such knowledge on his part. ${ }^{252}$ After this prima facie case is established it is possible for the defendant to come forward with proof indicating that although he intentionally indulged in the act of intercourse he did not do so with mens rea, because of a mistake of fact. ${ }^{253}$ Whether the proof offered will be sufficient for this purpose depends not only upon whether the mistake was based upon reasonable grounds but also upon the nature of the mistake. And the act under such circumstances as supposed by him may have involved too much of blameworthiness to permit this excuse, even if he could have avoided any criminal penalty had his conjecture been correct.

III

\section{Bigamy}

Problems of ignorance and mistake have presented unusual diffculties in connection with the crime of bigamy, and on some of the points involved the present state of the authorities is far from satisfactory. Difficulty is encountered even in the choice of words to be used in discussing the matter because a marriage ceremony in due form will not create the marital relation if either party has another spouse at the time. Such a ceremony is not in the true legal sense a marriage, nor is either party the lawful husband or wife of the other. Yet it is common to speak of a "bigamous marriage" and to define bigamy as the "offense of having a plurality of wives or husbands at the same time". 254

Quite obviously one charged with bigamy will not be excused because of ignorance of the statute prohibiting a second marriage by one

250. Plunkett v. State, 72 Ark. 409, 82 S. W. 845 (I904); People v. Pizzura, 21 I Mich. 7I, I78 N. W. 235 (I920); State v. Rollins, 80 Minn. 216, 83 N. W. I4I (I900).

25I. State v. Ruhl, 8 Iowa 447,450 (I859).

252. Fox v. State, 3 Tex. Cr. R. 329 (I877).

253. State v. Cody, III N. C. 725, I6 S. E. 408 (I892).

254. See, e. g., Ga. CODE (I933) §26-560r; MAY's Criminal Law (4th ed. by Sears and Weihofen, I938) \& I38. 
who has a lawful spouse living at the time, ${ }^{255}$ or because of a mistaken belief as to the impropriety and invalidity of such an enactment. ${ }^{256}$ The claim of ignorance or mistake of law in a bigamy case, however, almost invariably arises from some other angle. Thus a misconception of the marriage law may induce a bona fide belief of singleness based upon a false assumption of invalidity of a former marriage. Not even such a mistake of law is an excuse in a bigamy case, ${ }^{257}$ in the absence of some unusual provision in the statute. ${ }^{258}$ Hence one who has contracted a common-law marriage commits bigamy by marrying another woman while the first relation continues, even if he believes the first marriage invalid because it was not solemnized by the customary ceremony performed by clergyman or justice. ${ }^{259}$ And even reliance upon the advice of counsel that a former marriage with a cousin is void will not be an excuse for a second marriage with another. ${ }^{260}$

A mistaken belief of singleness by a married person may be due to the erroneous notion that the marriage tie has been dissolved by divorce, and this type of mistake may be either one of fact or one of law. If such a claim is made by one who knows just what steps were taken to obtain a divorce his mistake is one of law, if such steps were not sufficient to constitute a legal dissolution of the bonds of matrimony, and will not save him from conviction of bigamy if he marries another. ${ }^{261}$ On the other hand, if reliance is placed upon incorrect information to the effect that a divorce has been obtained by the spouse, the mistake is one of fact. In a bigamy case it is clear that the state is not required to allege and prove knowledge of the lack of divorce. ${ }^{262}$ The burden is on the defendant to establish his bona fide belief that his marriage had been dissolved by divorce, ${ }^{263}$ and reasonable grounds to support such belief. ${ }^{264}$ If his second marriage was contracted by him while entertaining a bona fide and reasonable belief of this nature, resulting from mistake of fact, he is entitled to an acquittal ${ }^{265}$ unless

255. Eldridge v. State, 126 Ala. 63,28 So. 580 (1899).

256. Reynolds v. United States, 98 U. S. 145 (I878); Long v. State, I92 Ind. 524, I37 N. E. 49 (1922).

257. People v. Hartman, I30 Cal. 487,62 Pac. 823 (1900) ; State v. Hughes, 58 Iowa I65, II N. W. 706 (I882) ; State v. Zichfeld, 23 Nev. 304, 46 Pac. 802 (I896).

258. The Georgia statute includes the word "knowingly". GA. CoDE (I933) \& 26560r. Quaere as to the interpretation.

259. State v. Zichfeld, 23 Nev. 304,46 Pac. 802 (1896).

260. Staley v. State, $89 \mathrm{Neb}$. 701, I3I N. W. 1028 (IgIr).

26I. State v. Armington, 25 Minn. 29 (1878); see Geisselman v. Geisselman, 134

Md. 453, 458, 107 Atl. 185, 187 (1919); cf. State v. Stank, 9 Ohio Dec. 8 (1883).

262. People v. Priestley, 17 Cal. App. I7I, I 18 Pac. 965 (I9II).

263. State v. Cain, 106 La. 708, 31 So. 300 (1902).

264. Ibid.; Lesueur v. State, I76 Ind. 448,95 N. E. 239 (19II). A mere rumor of death is insufficient basis for such belief. White v. State, I57 Tenn. 446, 9 S. W. (2d) 702 (1928).

265. Bigamy is regarded as extremely anti-social and is severely punished. Hence the mens rea requirement will be present unless excluded by the language of the statute. Regina v. Tolson, 23 Q. B. D. 168 (1889). 
something in the statute requires a different result. Some courts have held that innocence may be established by a proper showing of this nature ${ }^{200}$ while others have reached the opposite conclusion. ${ }^{267}$ Some of the cases can be distinguished by differences in the wording of the various statutes ${ }^{268}$ but more frequently there has been a disagreement as to construction. This can be considered to best advantage in connection with the problem which follows.

Still another type of mistake may lead to a married person's believing he is single. This is the erroneous belief that his spouse is dead, and is purely a mistake of fact. The general problem is similar to the mistake of fact that a divorce has been granted. Like such a mistake it will not excuse if not based upon reasonable grounds, ${ }^{209}$ but a bona fide and well grounded belief that the other spouse is dead should entitle the defendant to an acquittal in a bigamy case unless the language of the statute precludes this defense. ${ }^{270}$ Some interpretations have admitted this defense ${ }^{271}$ and others have not. ${ }^{272}$

Since it is within the power of the legislature in enacting the statute to include either more or less than the normal mens rea requirement, or to exclude this element entirely, it is necessary to consider each case in the light of the words used in that jurisdiction. Limitations of space permit only a very general comment on this subject here. The statutes differ from the extreme of stipulating "knowingly" as a special mental element of the offense ${ }^{273}$ to provisions which go rather far in the other direction. ${ }^{274}$ For the most part they provide two exceptions which are, in substance, (I) statutory presumption of death and (2)

266. Robinson v. State, 6 Ga. App. 696, 65 S. E. 792 (Ig09) ; Squire v. State, 46 Ind. 459 (1874); Lesueur v. State, 176 Ind. 448,95 N. E. 239 (I9II); State v. Sparacino, I64 La. 703, II4 So. 601 (1927); Baker v. State, 86 Neb. 775, I26 N. W. 300 (I910); State v. Stank, 9 Ohio Dec. \& (I883); Chapman v. State, 77 Tex. Cr. R. 59r, I79 S. W. 570 (I915); Adams v. State, 110 Tex. Cr. R. 20, 7 S. W. (2d) 528 (1928). 267. Rex v. Wheat, [192I] 2 K B. II9; Russell v. State, 66 Ark. I85, 49 S. W. 821 (I899); Ellison v. State, 100 Fla. 736, I29 So. 887 (1930); People v. Spoor, 235 III. 230,85 N. E. 207 (I908); Rogers v. Commonwealth, 24 Ky. L. Rep. II9, 68 S. W. I4 (Ig02); State v. Trainer, 232 Mo. 240, I34 S. W. 528 (I9I0); State v. Hendrickson, 67 Utah 15, 245 Pac. 375 (1926).

268. For example, compare Robinson v. State, 6 Ga. App. 696, 65 S. E. 792 (I909) with State v. Trainer, 232 Mo. 240, I34 S. W. 528 (I910).

269. Dotson v. State, 62 Ala. I4I (1878).

270. See a comparison of the bigamy statute and the adultery statute in State v. Audette, 81 Vt. 400,70 At1. 833 (-1908).

271. Regina v. Tolson, 23 Q. B. D. I68 (I889); Dotson v. State, 62 Ala. I4I (1878); Welch v. State, 46 Tex. Cr. R. 528, 81 S. W. 50 (I904).

272. Rand v. State, 129 Ala. II9, 29 So. 844 (1900); Cornett v. Commonwealth, I34 Ky. 6r3, I2I S. W. 424 (1909); Commonwealth v. Hayden, 163 Mass. 453,40 N. E. 846 (1895); State v. Goulden, I 34 N. C. 743,47 S. E. 450 (I904); State v. Ackerly, 79 V.t. 69,64 Atl. 450 (1906).

273. Ga. Code (1933) \$26-5601. See also id. \$26-5602. Compare Robinson y. State, 6 Ga. App. 693, 65 S. E. 792 (Ig09) with Parnell v. State, 126 Ga. 103, 54 S. E. 804 (1906).

274. Kan. Gen. Stat. Ann. (1935) §§ 21-901, 21-902. 
dissolution of the bonds of matrimony by judicial decree. The issue is whether the inclusion of these two exceptions impliedly excludes others not mentioned. The solution requires a careful examination of the purpose of these clauses.

Where one has left his home and not been heard from afterwards, an inference of death might arise in a relatively short time under some circumstances, whereas many years of absence and lack of information would fail to support such an inference if it was an obvious case of desertion by one who wished never to see his deserted spouse again. It would be so unwise to leave this matter unregulated that the statutes very generally provide for a statutory presumption of death in the event of absence for a certain period (varying from two ${ }^{275}$ to seven ${ }^{276}$ years) during which the absent one is not known to be alive by the other spouse. ${ }^{277}$ It is peculiarly important also for a bigamy statute to take a position on the matter of divorce because the state might (I) prohibit a divorcee from marrying any other person during the life of the original spouse, (2) distinguish between the innocent party and the guilty party in the divorce proceeding with reference to the right to remarry, ${ }^{278}$ or (3) permit either party to remarry after the divorce has become effective. Hence a clause on this subject is commonly included. 279

In other words, these are two exceptions which have nothing to do with ordinary crimes but are peculiarly important to bigamy. Because of this fact it seems out of line with sound principles of statutory construction to hold that the inclusion of these special and unusual defenses results in an implied exclusion of all general defenses, such as, for example, compulsion, insanity or mistake of fact. Moreover, had the cases which originally tested the issue been "shotgun marriages" enforced under the threat of immediate death, and marriages of insane persons, there would probably be no support for the view that bigamy is an offense with no requirement of mens rea. In

275. PA. Stat. Ann. (Purdon, 1930) tit. I8, \$6II. This statute requires a "false rumor, in appearance well founded" in addition to the two years' absence. Some statutes have a three year period without this additional requirement. See, for example, Fla. Comp. Gen. Laws AnN. (Ig27) §7560; N. H. Laws (I926) c. 386, §6.

276. See, e. g., ME. Rev. Stat. (I930) c. I35, §4; Miss. Code AnN. (1930) § 796.

277. See, e. g., Comp. Laws of Alaska (I933) \$ 4924; Cal. Pen. Code (I937) \$ 282; Fla. Conp. Gen. LAwS (I927) \$ 7560; IDAHo CoDE ANN. (I932) § I7-1803; Mass. Gen. Laws (I932) c. 272, \$ I5; Tex. Pen. Code (Vernon, I936) art. 495. Absence from the United States may be added as a separate clause. See, e. g., Ark. Dig. STAT. (I937) \$3294.

278. Massachusetts, for example, makes such a distinction. Mass. GEN. Laws (1932) c. $272, \S 15$.

279. See the statutes cited supra note 277 . The statute may also mention annulment and perhaps add a special clause on annulment because of nonage, thus making three clauses on the subject of judicial decree. ARK. Dig. Stat. (1937) § 3294. 
fact, there seems to be no case, and probably will be none, excluding the possibility of such defenses in a prosecution for bigamy. ${ }^{280}$ The much narrower issue presented by the decided cases is ( $I$ ) whether the statutory mention of absence and want of information for a certain period excludes bona fide belief of death based upon other reasonable grounds and (2) whether the reference to (actual) divorce excludes a reasonable mistake of fact that a divorce has been granted.

The most careful analysis is to be found in Regina $v$. Tolson ${ }^{281}$ which is the leading case for the view that the defenses mentioned in the statute do not necessarily exclude others of a more general nature. It is there pointed out that other evidence may indicate death much more convincingly than mere absence and want of information, and that it would be absurd to punish a wife for acting in bona fide reliance upon evidence strong enough to collect a policy of insurance or to probate a will-as where her second marriage is after she had watched the burial of a body, disfigured beyond recognition by an explosion, but confidently believed by her and by others in the community to be that of her first husband. ${ }^{282}$

What has come to be regarded as the leading case for the opposite view is Commonwealth $v$. Mash, ${ }^{283}$ in which the actual decision of guilt was unavoidable because the only basis for the belief of the husband's death was absence and want of information for substantially less than the statutory period. Language in this opinion quite beyond the needs of the decision has been relied upon by those courts which have regarded the inclusion of these special defenses as excluding any defense based upon the bona fide and reasonable belief of divorce or of death (unless supported by absence for the statutory period). The same court, it should be added, may interpret the statute as excluding one of these defenses but not the other. ${ }^{284}$

The wish to insure against the harsh interpretation reached by some of the courts has no doubt been responsible for the inclusion of certain special provisions in the bigamy statutes, such as the word "knowingly", 285 or an additional exception where the belief that the

280. Perhaps when cases have forced a more exhaustive analysis of the general problem it will be found there are no offenses without any requirement of mens rea, and that offenses now so classified merely have a narrower mems rea requirement than usual, which precludes certain defenses such as mistake of fact and misadventure.

28I. 23 Q. B. D. I68 (I889).

282. Id. at Igr.

283. 7 Metc. 472 (Mass. I844).

284. See, for example, Rex v. Wheat, [1921] 2 K. B. II9, which refused to recognize a bona fide and reasonable belief of divorce as a defense and distinguished Regina $v$. Tolson, in which the belief was of death. There is more reason for this distinction if the legislature in attempting to correct the situation gives as an additional excuse "good reason to believe such husband or wife to be dead" and fails to make similar provision for belief of divorce. See infra p. 70.

285. Ga. CODE (I933) \& 26-560r. Or "knowing", Colo. ANn. Stat. (I935) c. 48, § 201 ; Nev. CoMp. Laws (Hillyer, rg29) § 10r38. 
husband or wife is dead is based upon good grounds other than mere absence and want of information. ${ }^{286}$ The latter amendment takes care of one difficulty but tends to add strength to the argument against recognizing reasonable belief of divorce as an excuse. ${ }^{287}$ Assertions that bona fide belief resulting from reasonable mistake of fact is not a defense to bigamy in this country, ${ }^{288}$ or is not a defense here according to the weight of authority, ${ }^{289}$ seem not well grounded, ${ }^{290}$ but the problen is in urgent need of careful attention by courts and by legislative bodies.

286. Del. Rev. Code (r935) § 5255; Iowa CoDe (1935) § I2976; Mich. Conip. Laws (1929) § 16821 ; N. H. Laws (1926) c. 386, $\$ 6$; TEN N. CODE (Will. Shan. and Harlow, I932) \& III8I; VA. CoDE (Michie, I936) \$ 4539 .

287. White v. State, I 57 Tenn. 446, 9 S. W. (2d) 702 (1928).

288. Kenny, Outlines of Criminal Law (I5th ed. 1936) 363.

289. Clark and Marshall, Crimes (3d ed.) 86, n. 147.

290. Kenny cites no authorities. Clark and Marshall cite for the "prevailing view" cases from Alabama, Arkansas, Georgia, Illinois, Kentucky, Massachusetts, Minnesota, North Carolina, and Vermont. Ibid. To which might be added the cases cited supra note 267 from Florida, Missouri and Utah. But State v. Armington, 25 Minn. $29(18 ; 8)$, should be omitted because that involved a mistake of law. They cite for the other view, cases from Indiam Nebraska, Ohio and Texas. They do not mention the Louisiana case cited stipra note 266 , nor statutory provisions cited supra notes 285,286 , from Colorado, Delaware, Georgia, Iowa, Michigan, Nevada, New Hampshire, Tennessee and Virginia. 